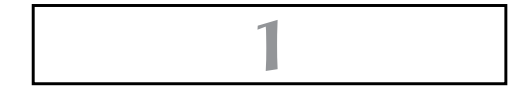

\title{
PLANEJAMENTO E ORÇAMENTO: ASPECTOS CONCEITUAIS E BREVE HISTÓRICO
}

\subsection{CONSIDERAÇÕES INTRODUTÓRIAS: O ORÇAMENTO E SUA FUNÇÃO COMO INSTRUMENTO DE PLANEJAMENTO}

"A lei orçamentária é a lei materialmente mais importante do ordenamento jurídico logo abaixo da Constituição", afirmou o Ministro Carlos Britto, por ocasião do julgamento da Ação Direta de Inconstitucionalidade (ADI) 4.048-1, em 2008. ${ }^{1}$ Uma frase que, embora proferida enquanto se debatia o tema de fundo ao longo das discussões que se travavam nessa paradigmática decisão de nossa Suprema Corte, há de ser recebida como a demonstração de uma verdade expressa em poucas e bem colocadas palavras.

A origem do orçamento se atribui ao art. 12 da Magna Charta Libertatum, de 1215, ao estabelecer que:

"Não serão lançados tributos sem consentimento do conselho geral do reino, a não ser para resgate da pessoa do Rei, para armar cavaleiro seu primogênito e para celebrar, uma única vez, o casamento da sua filha mais velha; e esses tributos não excederão limites razoáveis em seu montante. De igual maneira se procederá quanto aos impostos da cidade de Londres". ${ }^{2}$

1 STF, ADI 4.048-1/DF, Tribunal Pleno, Rel. Min. Gilmar Mendes, j. 14.5.2008.

2 Em tradução livre. No original: "12. No scutage or aid is to be levied in our realm except by the common counsel of our realm. Unless it is for the ramson of our body, the knighting of our eldest son or the first marriage of our eldest daughter, and for these only a reasonable aid is to be levied. Aids from the city of London are to be treated likewise" (Magna Carta. The Foundation of Freedom - 1215-2015). 
Mas o orçamento evoluiu muito ao longo desse longo período para atingir a condição da lei materialmente mais importante do ordenamento jurídico após a Constituição. Uma evolução que o fez passar de um documento estático, que apenas previa receitas e autorizava despesas, em sua concepção tradicional, para ser um instrumento de gestão e de planejamento. ${ }^{3}$ Deixa de ter prioritariamente essa função de instrumento de controle das despesas, que motivou sua criação, para ser uma ferramenta por meio da qual o Estado passa a conduzir-se, direcionando sua ação e a dos demais agentes econômicos. Estas últimas funções estão ainda em desenvolvimento e em implantação, e aquela como instrumento de planejamento - ainda em evolução, principalmente no que toca à implantação, - será o objeto central deste trabalho.

Essas novas funções, atualmente as principais, são reconhecidas e destacadas pelos estudiosos do tema.

Heleno Torres coloca o orçamento como verdadeiro

"meio transformador da sociedade segundo os fins e valores constitucionais do Estado. Este é o grande instrumento de ação dos governos e da sociedade para efetivar direitos e consagrar a justiça econômica, social e financeira em nosso País. Por isso, a grande revolução constitucional, no Brasil, será assumir o orçamento público sob a máxima efetividade que a Constituição Financeira postula, para dar concretude aos direitos e liberdades fundamentais, realizar o desenvolvimento, erradicar a pobreza e superar as desigualdades sociais e regionais ainda tão profundas”.

Após enfatizar a importância do orçamento, o jurista destaca sua função como instrumento de planejamento, ao ressaltar que

“toda a Administração sujeita-se às previsões orçamentárias que direcionam metas ou formulam programas a serem atingidos pelo Estado. Retirar do orçamento anual seu cariz programático equivaleria a convertê-lo numa mera conta de cunho estritamente contábil ou simples ato administrativo. Impõe-se, assim, uma interpretação sistemática para compreender o alcance material do plano plurianual em face do orçamento anual e de toda a Administração. Sua construção confere uma ampla gama de limitações à Administração, quanto à formação e aprovação dos orçamentos, bem como em relação às programações e planejamentos de natureza econômica" . ${ }^{4}$

Estevão Horvath assevera que, "sem sombra de dúvidas, um correto planejamento, devidamente juridicizado mediante a aprovação de leis correspondentes, e executado também da forma legalmente prevista, é o modo eficaz de contribuir

SILVA, José Afonso da. Orçamento-programa no Brasil, p. 37-44.

4 TORRES, Heleno Taveira. Teoria da constituição financeira, p. 769. 
para o atingimento dos ideais do Estado", plano governamental se dá por meio das leis orçamentárias (PPA, LDO e LOA) que, conjuntamente, estabelecem os mecanismos de concretização das políticas públicas, seja no plano social ou econômico" ${ }^{6}$

Adilson Dallari enfatiza a função do orçamento como instrumento de planejamento ${ }^{7}$ e mostra que sua evolução caminhou justamente nesse sentido. Nas palavras do jurista,

"desde sua origem até os dias de hoje, o orçamento público sofreu uma série de inovaçôes técnicas, aproximando-se cada vez mais de um processo de planejamento, chegando nos dias de hoje ao que se chama de orçamento-programa, que é a tradução em dotações ou verbas orçamentárias de um programa anual de governo. A propósito, a razão de ser do orçamento é exatamente a previsão dos gastos governamentais". ${ }^{8}$

Teixeira Ribeiro também evidencia esses papéis do orçamento. Para o jurista português, o orçamento desempenha basicamente três funções: 1) relacionação das receitas com as despesas, pois "o Estado tem de orçar as suas despesas e as suas receitas a fim de se assegurar de que estas bastam a cobrir aquelas"; 2) fixação das despesas, que configura "uma previsão de gastos que os serviços não poderão ultrapassar"; e 3) exposição do plano financeiro, pois "é nele que se concretiza o plano da Administração: o desenvolvimento que vai dar-se ou as restrições que vão pôr-se à actividade dos serviços, bem como a importância dos recursos que vão transferir-se do sector privado para o sector público”. E segue afirmando que

“(...) o orçamento não desempenha apenas as suas funçōes de relacionar as receitas com as despesas e de fixar as despesas. Pois, através da previsão destas, fica a saber-se quanto o Estado se propõe despender com a organização e funcionamento de cada um dos serviços; como, através da previsão das receitas, fica a saber-se qual o contributo de cada um dos meios de financiamento. O orçamento representa, portanto, o próprio programa financeiro. É nele que se concretiza o plano da Administração: o

5 HORVATH, Estevão. Orçamento público e planejamento. In: BANDEIRA DE MELLO, Celso Antonio (Org.). Estudos em homenagem a Geraldo Ataliba - Direito Tributário, p. 134.

6 HORVATH, Estevão. O orçamento no século XXI: tendências e expectativas, p. 320.

7 "Em síntese, a ordem jurídica, no tocante à disciplina das finanças públicas, não admite atuação empírica, incerta, insegura, desmedida ou mesmo aventurosa e temerária. Como se nota, a lei orçamentária não é uma lei qualquer. Trata-se de uma lei essencial, indispensável, que não pode faltar" (DALLARI, Adilson A. Lei orçamentária - processo legislativo. Peculiaridades e decorrências. Revista de Informação Legislativa, p. 158).

8 DALLARI, Adilson A. Lei orçamentária - processo legislativo, p. 158. 
desenvolvimento que vai dar-se ou as restrições que vão pôr-se à atividade dos serviços, bem como a importância dos recursos que vão transferir-se do sector privado para o sector público. Aqui temos, por conseguinte, a terceira função do orçamento: exposição do plano financeiro".

Para Dino Jarach, as funções do orçamento são basicamente:

“a) determinar en cifras y por un período de tempo la futura actividad del estado para el cumplimiento de los cometidos que ha asumido; b) permitir el conocimiento y el control, por parte de la opinión pública y del Poder Legislativo, de la actividad financiera del gobierno; c) evidenciar el cálculo económico de la actividad financiera del Estado a través del cotejo de los gastos y de los recursos aprobados por el Parlamento; d) coordinar el plan económico del sector público con el plan económico general (grifo nosso). Esta función, cuya importancia aparece más notoria en las finanzas modernas por el papel que asume el Estado al redistribuir la riqueza y tender a asegurar la estabilidad y el desarrollo económicos, no se puede excluir - tampoco - en el esquema de las finanzas clásicas, por las limitaciones que se imponen al Estado en cuanto a la asignación óptima de los recursos y a la neutralidad del plan presupuestario". ${ }^{10}$

Mais adiante, o jurista argentino fala sobre a necessidade de integração entre o Presupuesto financiero e o Plan Económico Nacional: "La idea general que las finanzas públicas constituyen (...) como promotor del desarrollo económico, sirven de base a la integración del Presupuesto financiero del Estado con el Plan económico nacional", ${ }^{11}$ mostrando ser esta, em destaque neste trabalho, uma importante função das ferramentas de planejamento orçamentário: a de integração entre os instrumentos de planejamento do Estado em âmbito nacional e os orçamentos públicos: “(...) Es éste un requisito de carácter instrumental para el propósito verdadero, que consiste en la integración del Presupuesto del Estado con el Plan económico nacional". ${ }^{12}$

Com grande clareza e objetividade, Sainz de Bujanda também identifica três funçôes fundamentais dos orçamentos, destacando a de ser instrumento de planejamento:

"Pero cuando se habla, dentro de nuestra disciplina, de las funciones del Presupuesto, hemos de referirnos a aquellas que tienen relevancia jurídica. Cuales son, así consideradas, tales funciones? Pienso que pueden reconducirse a tres fundamentales, a saber: organizar, controlar y programar. (...) El Presupuesto cumple una función programadora. Esto acontece cuando el plan financiero se instrumenta jurídicamente como

\footnotetext{
TEIXEIRA RIBEIRO, José Joaquim. Lições de finanças públicas, p. 57-59.

10 JARACH, Dino. Finanzas públicas y derecho tributario, p. 80-81.

11 JARACH, Dino. Finanzas públicas y derecho tributario, p. 96.

12 JARACH, Dino. Finanzas públicas y derecho tributario, p. 105.
} 
'parte' de un programa o plan económico general, que tiene, a su vez, su propia articulación jurídica. En los ordenamientos en que esto ocurre, el Derecho financiero ha de ocuparse de las relaciones entre las técnicas presupuestarias y la planificación económica, lo que constituye uno de sus ingredientes sistematizadores". ${ }^{13}$

A evolução das funções do orçamento é bem descrita pelos juristas franceses Michel Bouvier, Marie-Christine Esclassan e Jean-Pierre Lassale:

“(l)a fonction du budget a, d'autre part, évolué: dans um système d'Etat régalien le vote annuel du budget constituait l'acte politique majeur, à travers lequel le Parlement donnait aux services publics les moyens de fonctionner. Cette simplicité dans les objectifs s'est estompée à l'époque contemporaine, avec l'intégration de plus em plus poussée des finances publiques dans l'économie générale. Le budget est devenu un instrument conjoncturel. Il doit s'adapter et corriger les fluctuations économiques, don't il est par ailleurs étroitement dépendant en ce qui concerne ses ressources". ${ }^{14}$

Atualmente, não há como deixar de reconhecer ser o planejamento a função por excelência dos orçamentos públicos, que não mais podem ser vistos de forma isolada, apenas como sinônimos da Lei Orçamentária Anual. Esta passa a se contextualizar em um sistema mais amplo de planejamento governamental, mais especificamente no que ora denominamos planejamento orçamentário da Administração Pública, que, no Brasil, abrange as demais leis de natureza orçamentária já citadas, o Plano Plurianual e a Lei de Diretrizes Orçamentárias.

\subsection{O PLANEJAMENTO ORÇAMENTÁRIO DA ADMINISTRAÇÃO PÚBLICA: DELIMITAÇÕES DO CONTEÚDO E APROXIMAÇÃO DO CONCEITO}

Planejamento é uma expressão de significado variado, múltiplo e amplo, e não se pode dizer que tenha um conceito preciso. Usado por diversos ramos científicos, é multidisciplinar, e, mesmo no âmbito do Direito, ainda comporta várias interpretaçôes, tornando necessário delimitar e tornar mais preciso seu conteúdo. Uma busca em qualquer dicionário mostrará essa multiplicidade de significados, vários dos quais nenhuma relação ou interesse têm para este trabalho, mas evidenciam não ser simples extrair o exato conteúdo dessa palavra.

Pretende-se nesta obra analisar aspectos específicos do planejamento, a serem descritos e delimitados a fim de ter um foco do tema que se pretende abordar.

13 SAINZ DE BUJANDA, Fernando. Sistema de derecho financiero, p. 417-419.

14 BOUVIER, Michel; ESCLASSAN, Marie-Christine; LASSALE, Jean-Pierre. Finances publiques, p. 249. 
De início, cumpre notar, desde logo, que, entre as diversas áreas do saber, o planejamento é objeto de estudo e aplicação na Administração, pública e privada, na Economia, na Engenharia, e, em praticamente todas as áreas, há, de alguma forma, a referência ao planejamento.

Restringindo-se ao Direito, vê-se especial referência ao planejamento nas áreas do Direito Financeiro, do Direito Econômico, do Direito Administrativo e do Direito Tributário, entre outras, em cada uma delas com abrangência, alcance e significado próprios, que por vezes se inter-relacionam, mas nem sempre são coincidentes.

Como já exposto, esta obra abordará o tema no âmbito do Direito Financeiro, que tem como objeto de estudo os princípios e as regras que regem a atividade financeira do Estado, compreendendo a arrecadação de receitas, orçamento, despesas, controle, partilha federativa e responsabilidade fiscal. ${ }^{15}$ É nesse aspecto que se concentrará a investigação sobre os diversos pontos que serão abordados, de modo que se pretende alcançar os diversos objetivos propostos pelo trabalho pela análise a partir de aspectos jurídicos do planejamento no âmbito das finanças públicas, usualmente denominado planejamento do setor público ou planejamento governamental, ${ }^{16}$ e que, conforme será exposto, melhor se ajusta, para os fins específicos desta tese, a ser chamado de Planejamento orçamentário da Administração Pública.

Nem sempre é fácil delimitar com absoluta precisão as fronteiras entre as diversas concepções passíveis de haver do planejamento governamental, e, em algumas delas, essas linhas demarcatórias terão menor nitidez, como é o caso daquelas que delimitam os campos entre o Direito Financeiro e o Direito Econômico no trato do tema.

Não se tem a pretensão de apresentar definições e conceitos absolutamente precisos, que permitam conclusóes definitivas sobre o tema; no entanto, almeja-se ser possível distinguir com melhor nitidez o objeto de estudo de forma a possibilitar a compreensão da existência de uma concepção específica do planejamento

OLIVEIRA, Regis F. Curso de direito financeiro, p. 106-107.

16 Não se pretende estabelecer distinção entre essas expressões para os fins deste trabalho, que as utilizará indistintamente, com o mesmo significado, até mesmo para que se permita reproduzir as palavras utilizadas pelos diversos autores que tratam do tema. A expressão "planejamento governamental", registre-se, é utilizada pela legislação brasileira, como se vê da Lei n. 13.249, de 2016, que instituiu o Plano Plurianual para o período 2016-2019 ("Art. 2: O PPA 2016-2019 é instrumento de planejamento governamental que define diretrizes, objetivos e metas..."). 
governamental no âmbito do Direito Financeiro, com contornos e características próprios, cujo enfoque dar-se-á nos seus aspectos orçamentários.

O próprio texto constitucional permite reconhecer um tratamento diferenciado no ponto em que há maior proximidade na concepção de planejamento governamental, que são as áreas do Direito Econômico e do Direito Financeiro.

$\mathrm{O}$ art. 174 da Constituição, que integra o Título VII, "Da ordem econômica e financeira", estabelece que, "Como agente normativo e regulador da atividade econômica, o Estado exercerá, na forma da lei, as funções de fiscalização, incentivo e planejamento, sendo este determinante para o setor público e indicativo para o setor privado", e continua no $₫ 1^{\circ}$ dispondo que "A lei estabelecerá as diretrizes e bases do planejamento do desenvolvimento nacional equilibrado, o qual incorporará e compatibilizará os planos nacionais e regionais de desenvolvimento" (grifo nosso). $\mathrm{O}$ art. 21, IX, da Constituição, ao cuidar das competências da União, estabelece que lhe cabe "elaborar e executar planos nacionais e regionais de ordenação do território e de desenvolvimento econômico e social".

$\mathrm{O}$ art. 165, por seu turno, ao tratar dos orçamentos públicos, estabelece que "Leis de iniciativa do Poder Executivo estabelecerão: I - o plano plurianual; II - as diretrizes orçamentárias; III - os orçamentos anuais".

Ambas são normas que claramente tratam do planejamento governamental.

A primeira concepção, integrando essencialmente o objeto de estudo do Direito Econômico, que se ocupa da ordenação jurídica da política econômica do Estado, ${ }^{17}$ é a que podemos denominar planejamento econômico governamental. Evidentemente, a expressão abrange aspectos mais amplos do planejamento governamental, incluindo, por exemplo, os sociais, sendo também coerente denominá-la planejamento econômico-social governamental, mas entendo adequada e suficiente a primeira expressão, compreendida em seu sentido amplo. Vê-se também que é uma concepção do planejamento voltada ao âmbito nacional, compreendendo o Estado como um todo, na qual se ajustam melhor as discussões sobre seus rumos e políticas de caráter geral, ainda que se possam desdobrar em setores e regiōes específicas, mas sempre tendo em vista a nação em seu conjunto. É o planejamento do desenvolvimento nacional, como bem coloca Eros Grau, ou, por referir-se essencialmente à atividade econômica do Estado, o planejamento do desenvolvimento econômico. ${ }^{18}$

17 GRAU, Eros. A ordem econômica na Constituição de 1988, p. 149.

18 GRAU, Eros. A ordem econômica na Constituição de 1988, p. 303. 
Um planejamento que já se caracteriza como um instrumento fundamental para o desenvolvimento, como bem destacado por Gilberto Bercovici, referindo-se ao planejamento nessa concepção lato sensu:

"O planejamento é absolutamente necessário para a promoção do desenvolvimento. As atividades do Estado devem ser coordenadas para o desenvolvimento econômico e social e esta coordenação se dá por meio do planejamento, que não se limita a definir diretrizes e metas, mas determina, também, os meios para a realização destes objetivos". ${ }^{19}$

A segunda, que se insere no objeto de estudo do Direito Financeiro, e cuida do planejamento em cada ente da federação, por meio das leis orçamentárias, constituindo-se em um planejamento orçamentário governamental. Essa acepção de planejamento, não obstante também se destine a todo o Estado, tem um caráter essencialmente instrumental, ${ }^{20}$ voltado à Administração Pública, motivo pela qual pode ser também denominada planejamento orçamentário da Administração Pública, e se operacionaliza basicamente por leis próprias de cada um dos entes federados, razão pela qual o centro de suas preocupações está nas técnicas e nos meios jurídicos por meio dos quais a Administração Pública (em seu sentido lato, ou conjunto de administrações públicas, caso acolhida uma acepção mais restrita, admitindo-se uma para cada ente da Federação) materializará e coordenará as ações governamentais com as quais promoverá o bem comum e atingirá seus objetivos. ${ }^{21}$

O próprio texto constitucional permite essa interpretação. $\mathrm{O}$ art. 174 fala que, como agente normativo (...), o Estado exercerá (...), e o art. 165, $\$ 1^{\circ}$, faz expressa referência à Administração Pública Federal.

19 BERCOVICI, Gilberto. Desigualdades regionais, estado e constituição, p. 191.

20 O caráter instrumental do planejamento, a essência do planejamento orçamentário, é destacado em vários autores, como se vê em Diogo de Figueiredo Moreira Neto: "Em suma, o planejamento estatal deve ser entendido nada mais do que um conceito instrumental: mera técnica social para programar e desenvolver a correta concentração de poder necessária para que possa ser eficientemente empregada pelo aparelho administrativo do Estado para a racionalização de suas próprias atividades, em suas diversas funçôes; sempre operando sob diretrizes constitucionais e em benefício da sociedade, na concentração e direção dos meios que dela retira para alcançar as finalidades de interesse geral" (Curso de direito administrativo, p. 580-581).

21 James Giacomoni identifica que a Constituição brasileira "concebe duas modalidades de planos", de forma assemelhada ao que foi exposto. "A primeira envolve os chamados planos de desenvolvimento econômico e social e está a serviço da concepção do Estado intervencionista. Tais planos assumem papel determinante para o setor público e indicativo para o setor privado (...) A outra modalidade é o plano plurianual, voltado à programação da Administração Pública e claramente idealizado como guia plurianual para as autorizações orçamentárias anuais" (Orçamento público, p. 193, grifo nosso). 
É nessa segunda concepção que concentraremos este estudo, ainda que não o façamos de forma exclusiva, pois, como se poderá ver ao longo do texto, as diversas noçôes do planejamento governamental serão sempre necessárias para explicitar as ideias que se pretende desenvolver.

Demonstrar-se-á que o planejamento orçamentário da Administração Pública é instrumento fundamental e imprescindível para que os Estados - em especial o brasileiro, no qual se concentrará a análise a ser efetuada -, atinjam os objetivos a que se propuseram.

A República Federativa do Brasil tem seus objetivos fundamentais expressos no art. $3^{\circ}$ da Constituição:

a) construir uma sociedade livre, justa e solidária;

b) garantir o desenvolvimento nacional;

c) erradicar a pobreza e a marginalização e reduzir as desigualdades sociais e regionais; e

d) promover o bem de todos, sem preconceitos de origem, raça, sexo, cor, idade e quaisquer outras formas de discriminação.

Esses objetivos, como se pretende demonstrar, somente serão atingidos na sua plenitude, no tempo e modo adequados, com a institucionalização e a efetiva implantação de um sistema de planejamento orçamentário da Administração Pública que coordene os recursos naturais, humanos, materiais e financeiros de forma eficiente, e que seja capaz de conduzir os esforços de nossa sociedade harmonicamente para alcançá-los e torná-los uma realidade.

\subsection{ACEPÇÕES DO TERMO PLANEJAMENTO | PLANEJAMENTO ECONÔMICO, PLANEJAMENTO ORÇAMENTÁRIO, PLANO, PROGRAMAÇÃO, POLÍTICA PÚBLICA}

O planejamento do setor público compreende um complexo conjunto de atos que se coordenam para fixar e alcançar objetivos almejados pelo Estado.

De início, é relevante destacar que, sendo o planejamento um tema multidisciplinar, objeto de estudo por várias ciências, como já ressaltado, para o Direito interessam as normas pelas quais se efetivará. ${ }^{22}$

22 Nesse sentido, Floriano Marques Neto e João Eduardo Queiroz expõe que, para a Economia, o planejamento é uma subordinação dos fatores econômicos a um plano preestabelecido pelo Poder Público, enquanto, para o Direito, planejamento é a normatização da institucionalização das transformações sociais e econômicas (Planejamento. In: CARDOZO, José 
O Professor Eros Grau, em sua obra de referência no tema, conceitua o planejamento econômico como a

"forma de ação estatal, caracterizada pela previsão de comportamentos econômicos e sociais futuros, pela formulação explícita de objetivos e pela definição de meios de ação coordenadamente dispostos, mediante a qual se procura ordenar, sob o ângulo macroeconômico, o processo econômico, para melhor funcionamento da ordem social, em condiçôes de mercado". ${ }^{23}$

Em sentido semelhante, bem pontua Gilberto Bercovici, para quem "o fundamento da ideia de planejamento é a perseguição de fins que alterem a situação econômica e social vivida naquele momento. É uma atuação do Estado voltada essencialmente para o futuro". ${ }^{24} \mathrm{O}$ planejamento, como ressalta este mesmo autor, em uma concepção acolhida por muitos estudiosos do tema,

"coordena, racionaliza e dá uma unidade de fins à atuação do Estado, diferenciando-se de uma intervenção conjuntural ou casuística. $\mathrm{O}$ plano é a expressão da política geral do Estado. É mais do que um programa, é um ato de direção política, pois determina a vontade estatal por meio de um conjunto de medidas coordenadas, não podendo limitar-se à mera enumeração de reivindicaçōes". ${ }^{25-26}$

Importa destacar que, nesta hipótese, vê-se o planejamento como um conceito de dimensão mais ampla, abrangendo a coordenação das atividades governamentais voltadas ao futuro, em uma perspectiva macroeconômica, para perseguir objetivos que alterem a situação econômica e social, a partir de uma visão do Estado, sendo o plano uma materialização da expressão da política geral deste.

Eduardo M.; QUEIROZ, João Eduardo L.; SANTOS, Márcia Walquiria B. (Coord.). Direito administrativo econômico, p. 686).

MARQUES NETO, Floriano; QUEIROZ, João Eduardo. Planejamento, p. 65.

BERCOVICI, Gilberto. Planejamento e políticas públicas. In: BUCCI, Maria Paula Dallari (Org.). Politicas públicas. Reflexões sobre o conceito jurídico, p. 146.

BERCOVICI, Gilberto. Planejamento e políticas públicas, p. 145.

Como se pode observar em outros textos específicos sobre o tema, exemplificando com o artigo de Mauro Giacobbo, que destaca a precedência do planejamento sobre os demais atos da administração ("O planejamento é a primeira das funções básicas a administração (planejamento, organização, direção e controle), pois serve exatamente de base para as demais funçôes. O planejamento define onde se pretende chegar, o que deve ser feito, quando, como e em que sequência, gera ações") e a sua característica de ser também um processo que compreende um conjunto de atos coordenados e sucessivos: "também o planejamento precisa ser entendido como um processo, ou seja, um conjunto de passos e procedimentos combinados e executados em sequência a fim de produzir um resultado" (O desafio da implementação do planejamento estratégico nas organizações públicas. Revista do Tribunal de Contas da Uniāo, p. 75-76). 
É nesse ponto que importa evidenciar que o planejamento governamental, no seu aspecto orçamentário, ao qual passamos a nos referir como planejamento orçamentário da Administração Pública, compreende justamente essa materialização do planejamento do Estado na Administração Pública, que se concretizará, a médio e curto prazos, nas leis orçamentárias previstas na Constituição para cada um dos entes da Federação. Não há que se confundir, pois, um planejamento, no mais das vezes, nacional, do Estado, a que preferimos conceber no bojo da ideia de planejamento econômico governamental, com o planejamento expresso nas leis orçamentárias de cada ente federado.

O planejamento, a que se refere Bercovici, "está, assim, sempre comprometido axiologicamente, tanto pela ideologia constitucional como pela busca da transformação do status quo econômico e social", não existindo planejamento "neutro", "pois se trata de uma escolha entre várias possibilidades, escolha guiada por valores políticos e ideológicos, consagrados, no caso brasileiro, no texto constitucional". ${ }^{27}$ No mesmo sentido, alinha-se Cabral de Moncada, em outra obra de leitura indispensável sobre o planejamento econômico:

"A planificação surge como um processo de intervenção do Estado, qualificada por certas características especiais, já apontadas, e oferece-se como uma metodologia axiologicamente não neutra, ou seja, comprometida, porque entra sempre em conflito com o 'status quo' económico e social recusando-lhe as consequências globais". ${ }^{28}$

De fato. No entanto, esse planejamento é o que estamos chamando planejamento econômico governamental, em que, politicamente, serão feitas as escolhas destinadas a conduzir o Estado - no caso, o Brasil - na direção de atingir os objetivos fundamentais consagrados na Constituição.

Nesse sentido, quando Bercovici diz, com propriedade, que

"o planejamento não pode ser reduzido ao orçamento (...) porque perde sua principal característica, a de fixar diretrizes para a atuação do Estado (...) que servem também de orientação para os investimentos do setor privado. (...) A redução do plano ao orçamento é apenas uma forma de coordenar mais racionalmente os gastos públicos, não um verdadeiro planejamento, voltado ao desenvolvimento, ou seja, à transformação das estruturas socioeconômicas". ${ }^{29}$

E, mais recentemente, no mesmo sentido, completa, ressaltando a injustificável omissão do Estado brasileiro em sua função planejadora nos termos previstos pelo art. 174:

27 BERCOVICI, Gilberto. Desigualdades regionais, estado e constituição, p. 192-193.

28 MONCADA, Luís S. Cabral de. A problemática jurídica do planeamento económico, p. 46.

29 BERCOVICI, Gilberto. Desigualdades regionais, estado e constituição, p. 208. No mesmo sentido, manifesta-se no texto "Planejamento e políticas públicas", p. 157. 
"Apesar da crise, na Constituição de 1988 foi prevista a obrigação da função de planejamento para o Estado em seu artigo 174, caput: 'Como agente normativo e regulador da atividade econômica, o Estado exercerá, na forma da lei, as funçóes de fiscalização, incentivo e planejamento, sendo este determinante para o setor público e indicativo para o setor privado'. O Estado brasileiro, portanto, não pode se limitar a fiscalizar e incentivar os agentes econômicos privados; deve também planejar. $\mathrm{O}$ modelo de planejamento previsto na Constituição de 1988 visa à instituição de um sistema de planejamento com grande participação do Poder Legislativo, nível elevado de compatibilidade entre plano e orçamento, e sua subordinação aos objetivos fundamentais da República, expressos, por exemplo, no artigo $3^{\circ}$ do texto constitucional. $\mathrm{Na}$ Constituição, estão estipuladas as bases para um planejamento democrático, com aumento da transparência e controle sobre o gasto público, ao exigir coerência entre o gasto anual do governo e o planejamento de médio e longo prazos. A grande dificuldade situa-se na falta de vontade e/ou condição política para implementar novamente o planejamento estatal. Essa falta de vontade e/ou condição política em planejar é patente no descumprimento da determinação constitucional de estabelecimento de uma legislação sistemática do planejamento, conforme o artigo 174, parágrafo $1^{\circ}$, que, até hoje, não foi elaborada de maneira adequada. Ou seja, desde 1979, com a revogação dos atos institucionais e complementares, o Brasil não possui nenhuma lei que regule o planejamento nacional. A Lei 10.180, de 6 de fevereiro de 2001, embora pretenda organizar 'sob a forma de sistema' as atividades de planejamento, não institui um verdadeiro Sistema Nacional de Planejamento, nos termos do artigo 174, parágrafo $1^{\circ} \mathrm{da}$ Constituição de $1988{ }^{30}$

Refere-se o professor de Direito Econômico ao ora denominado planejamento econômico governamental, no que suas palavras fazem todo o sentido.

No entanto, não vemos como possível a viabilização do planejamento (no sentido dado pelos autores ora citados à expressão, que preferimos definir, repetimos, como planejamento econômico governamental) sem a redução deste, em algum momento, aos orçamentos públicos, compreendidos estes em seu sentido mais amplo, abrangendo não somente as leis orçamentárias anuais, mas também os planos plurianuais e as leis de diretrizes orçamentárias (para exemplificar na hipótese brasileira) - ou seja, mediante a utilização de um sistema de Planejamento orçamentário da Administração Pública (que a professora portuguesa Nazaré Cabral prefere denominar "programação orçamental”, como se verá mais adiante).

Isto porque, ao planejar a ação do Estado, uma vez feitas as escolhas, há necessidade de concretizá-las, transformando-as em medidas efetivas que permitam

30 BERCOVICI, Gilberto. O planejamento do Estado não pode ser reduzido ao orçamento. Consultor Jurídico, p. 1. 
conduzir a Administração Pública, caso em que o planejamento passa a assumir uma função de natureza mais técnica, reduzindo-se a discricionariedade do administrador, a quem competirá dar cumprimento ao que foi estabelecido. O sistema de planejamento orçamentário passa a ser um caminho institucional percorrido para o cumprimento dos objetivos fundamentais da República brasileira e a consequente realização dos direitos sociais. ${ }^{31}$

É nesse momento que identificamos o que já foi explicitado como Planejamento orçamentário da Administração Pública, quando as escolhas políticas que resultaram em definição concreta das ações governamentais a serem implementadas serão transformadas em documentos - no caso brasileiro, essencialmente, nas leis orçamentárias (PPA, LDO e LOA, como se verá a seguir).

Outros autores têm essa mesma percepção. Giuliani Fonrouge aponta as características particulares daquele que chama orçamento financeiro em contraste com o também por ele denominado orçamento econômico, que refletiria a atividade econômica do Estado. Essa distinção se aproxima daquela que foi feita, até aqui, entre planejamento orçamentário e planejamento econômico:

"A diferencia del concepto tradicional, la doctrina moderna considera al presupuesto del Estado - el presupuesto financiero propiamente dicho - como parte integrante de un documento más amplio, que refleja toda la actividad económica de la Nación y que, por esto, se denomina presupuesto nacional, o presupuesto económico o presupuesto económico de la Nación, y es concebido como 'un acto de previsión integral de los ingresos y gastos probables de la Nación durante determinado período”.

Esse orçamento econômico mencionado por Fonrouge não seria, como o próprio ressalta, um orçamento propriamente dito, mas um conjunto de informações econômicas.

"En realidad no corresponde exagerar la oposición entre el concepto tradicional y el moderno, pues para hablar con propiedad, el presupuesto económico no es un 'presupuesto' en el sentido técnico del vocablo, 'sino más bien una cuenta nacional, un cuadro económico que facilita la administración de los recursos nacionales por el Estado', carente de contenido jurídico y que no constituye un acto legal y obligatorio; simplemente, es un 'instrumento de orientación'. Por lo demás, el presupuesto económico no reemplaza ni absorbe al presupuesto financiero, ya que tiende a completarlo, porque, en suma, constituye un elemento de información para la adecuada confección del presupuesto financiero" ${ }^{32}$

31 Nas palavras de Luiz Fernando Arantes Paulo, "O sistema de planejamento e orçamento é o caminho institucional para a realização dos direitos sociais" (Os caminhos para os direitos sociais na Constituição brasileira. Revista Brasileira de Orçamento Público, p. 19).

32 FONROUGE, Giuliano Carlos M. Derecho financiero, p. 147-148. 
Sainz de Bujanda evidencia também esse planejamento de natureza econômica ao fazer referência a "un Presupuesto nacional, cuyo fin es establecer una eficaz coordinación entre la actividad financiera del Estado y el desenvolvimiento general de la economía del país" ${ }^{33}$ E deixa bastante clara a necessária relação entre os instrumentos de planejamento:

"En esquema, puede afirmarse que los ordenamientos conocen tres tipos de instrumentos de política económico-financiera, a saber: $1^{\circ}$ El Plan económico - vinculante, indicativo o mixto -; $2^{\circ}$ El Presupuesto financiero público-estatal o de otro nivel político y administrativo; y $3^{\circ}$ Los Informes económico-financieros que explican y enmarcan la aplicación del Presupuesto. Un Sistema de derecho financiero tiene, pues, que plantearse estos problemas: $1^{\circ} \mathrm{La}$ conexión jurídica entre el Plan - cuando existe - y el Presupuesto; $2^{\circ}$ El tratamiento, dentro del sector público, de una pluralidad de Presupuestos financieros, y $3^{\circ} \mathrm{El}$ valor jurídico de los llamados 'Informes económico-financieros". ${ }^{34}$

Heleno Torres segue na mesma linha, evidenciando a conexão necessária do planejamento orçamentário com o dirigismo estatal para dar eficácia ao sistema de planejamento econômico: "O planejamento orçamentário é o mínimo de eficácia do art. 174, que não se pode limitar ou bastar por estes, de duração restrita no tempo, mas que permite sua conexão com a regulação da ordem econômica e com o dirigismo estatal", sendo esta exatamente "a relação que se coloca entre o planejamento das leis de orçamento (programas de curto prazo) com o regime constitucional de planejamento do art. 174 da CF, de amplitude maior e de longa duração" ${ }^{35}$

O planejamento orçamentário da Administração Pública materializa-se em planos - no Brasil, juridicamente, temos, como principais documentos representativos deles, as já citadas três leis de natureza orçamentária, a saber, o Plano Plurianual (PPA), que representa o que pode ser considerado um planejamento (ou plano) de médio prazo, a Lei de Diretrizes Orçamentárias (LDO) e a Lei Orçamentária Anual (LOA), documento que, além de cumprir as funções próprias do orçamento público, materializa um planejamento de curto prazo; e a LDO exerce verdadeiro "elo" entre o PPA e a LOA. ${ }^{36}$

33 SAINZ DE BUJANDA, Fernando. Hacienda y derecho. Introducción al derecho financiero de nuestro tiempo, p. 79.

34 SAINZ DE BUJANDA, Fernando. Sistema de derecho financiero, p. 436.

35 TORRES, Heleno Taveira. Direito constitucional financeiro. Teoria da constituição financeira, p. 352-353.

36 Cabe observar desde já, para retomar o debate oportunamente, que não houve uma definição clara das funções do PPA, conforme ressalta Weder de Oliveira, por parte do legislador cons- 
Admissível, como se pode entrever da opinião de alguns autores, que aquilo que ora se denomina planejamento orçamentário da Administração Pública seja, na verdade, um plano, ou, melhor expressando, conjunto ou sistema de planos, e não propriamente um planejamento, expressão que se reservaria apenas ao âmbito do planejamento econômico governamental.

Com efeito. Para o jurista Eros Grau, planejamento não se confunde com plano, que é "a expressão documental da projeção de uma série de atos de intervencionismo". ${ }^{37} \mathrm{Em}$ se utilizando das palavras de Carlos Matus, segundo o qual "o plano é o produto momentâneo do processo pelo qual um ato seleciona uma cadeia de ações para alcançar seus objetivos", e, mais adiante, "um plano é um compromisso que anuncia resultados, ainda que tais resultados não dependem inteira ou principalmente do cumprimento daqueles compromissos", ${ }^{38}$ é possível compreender tais documentos como "planos", admitindo-se essa acepção, que pode ser considerada mais restrita, do termo. ${ }^{39}$

Por sua vez, a expressão "plano", se analisada em sua acepção ampla, não se mostra de todo adequada para definir a "redução" do planejamento econômico governamental ao orçamento. Muitos dos planos já implementados, e outros por implementar, como os que se referem a setores específicos da atuação do Estado, por exemplo, o Plano Nacional de Educação, o Plano Nacional de Cultura e outros, são documentos que até mesmo trazem disposições de natureza orçamentária, mas não se resumem a elas, nem chegam a representar o aspecto principal dos referidos documentos, que traduzem diretrizes de caráter nacional, abrangendo

tituinte. "Não soube dizer com consistência e coerência o que pretendia com o PPA: não queria um instrumento semelhante ao fracassado orçamento plurianual de investimentos (OPI), anteriormente vigente, e por outro lado também não fez dele um instrumento de planejamento global do Estado, destinando-o apenas às despesas de capital e programas de duração continuada, conferindo-lhe porém posição do mais alto relevo, submetendo a ele planos e programas nacionais, regionais e setoriais previstos na Constituição" (Curso de responsabilidade fiscal, p. 310).

37 GRAU, Eros. Planejamento econômico e regra jurídica, p. 76.

38 MATUS, Carlos. O plano como aposta. In: GIACOMONI, James; PAGNUSSAT, José Luiz (Org.). Planejamento e orçamento governamental, p. 115.

39 E ao se falar em "plano", no contexto de planejamento, não há que se considerar tais os atos da administração que recebem essa denominação, mas pouco ou nada se relacionam com a atividade planejadora do Estado. É o caso, por exemplo, dos "planos" de estabilização monetária, como os ocorridos no Brasil, a exemplificar com os chamados "Plano Cruzado", "Plano Bresser", "Plano Verão" e outros, cujas finalidades não estão voltadas a definir objetivos da administração, sendo verdadeiramente atos que configuram verdadeiramente um "não planejamento", na bem colocada expressão de Eros Grau (A ordem econômica na Constituição de 1988, p. 303). 
diversos aspectos de interesse para o desenvolvimento das políticas públicas do respectivo setor.

A utilização da expressão "planejamento" para referir-se ao sistema que se compõe, entre outros instrumentos, pelas leis de natureza orçamentária, por meio das quais se operacionaliza a condução dos rumos, a médio e curto prazos, do Estado, abrangendo todos os entes da Federação, é mera questão semântica, de escolha de uma expressão que permita identificar e compreender esse fenômeno.

Washington Peluso Albino e Souza também traz sua contribuição ao tema, distinguindo "planejamento" de "plano". Segundo o destacado professor de Direito Econômico, o planejamento, também denominado "planificação",

“constitui o 'ato de planejar', e prende-se essencialmente à ideia de racionalizar o emprego de meios disponíveis para deles retirar os efeitos mais favoráveis. Seu conceito está intimamente ligado ao sentido do que seja o 'econômico', visto como este traduz o intuito de obter a 'maior vantagem' do emprego dos meios escassos, para a sua consecução. Levada adiante a ideia da 'planificação' como 'ação de planejar', poderemos esmiuçar mais o sentido do termo 'Planejamento' e atribuir-lhe ligação íntima com a adoção de 'planificação', isto é, a 'determinação' (já de natureza política) de se aplicar a 'planificaçãa' como método de intervir, ou seja, de concretizar a intervenção do Estado no domínio econômico". ${ }^{40}$

Vê-se que a concepção do autor do termo planejamento é estreitamente ligada à noção que se procura estabelecer de planejamento econômico governamental. E continua o autor, distinguindo do que se concebe por "plano":

“Neste caso, 'plano' é o documento, a 'peça técnica' decorrente da 'ação de planejar', da 'planificação', quando se adota a orientação político-econômica de 'intervenção' pelo 'Planejamento'.

Chamaremos, portanto, ao 'plano' de 'peça técnica', na fase de documento no qual estão inseridos os elementos que definem a situação econômica e indicam medidas para que possam ser atingidos os 'objetivos' considerados convenientes pelos seus elaboradores". ${ }^{41}$

E segue mostrando que o plano representa a expressão técnica dos estudos e está em um estágio anterior à apreciação de natureza política, atingindo-se a fase de planejamento quando tiver base legal, e o plano passar a ser expresso em uma lei. E, então, a 'lei do plano' passa a ter legitimidade na ordem jurídica do Estado de Direito, sedo instrumento fundamental da política econômica. ${ }^{42}$

40 SOUZA, Washington Peluso A. Primeiras linhas de direito econômico, p. 372.

41 SOUZA, Washington Peluso A. Primeiras linhas de direito econômico, p. 372.

42 SOUZA, Washington Peluso A. Primeiras linhas de direito econômico, p. 372-373. 
Mais à frente, deixa evidente que a linguagem técnica em matéria de planejamento não tem unanimidade, fazendo referência às diversas expressões empregadas, como "plano", "projeto", "programa”, "metas" e "objetivos":

'O 'Plano' seria o documento amplo, final. Compor-se-ia de 'projetos', que seriam como que o desdobramento detalhado do Plano, em seus 'objetivos'. O 'Programa', de âmbito limitado, figuraria, ou não, como parte do Plano. Por sua vez, os 'Objetivos' são fundamentais na estrutura de ambos. Constituem os resultados finais e completos a serem atingidos. Tanto 'Plano' quanto 'Programa' desdobram-se em 'metas', ou seja, em partes ligadas a um sentido sequencial e que, uma vez completadas, garantirão o cumprimento dos 'Objetivos'. (...) essa terminologia costuma ser confundida pelos próprios técnicos de Planificação, entre nós, que chegaram a apresentar ao País um 'Plano de Metas'. Se lhe tivessem dado o sentido de conjunto, apesar de seu tratamento por partes, teria sido melhor denominá-lo 'Metas de um Plano'”. ${ }^{43}$

A multiplicidade de conceitos e a dificuldade de dar-lhes um delineamento uniforme são bem expostas por Floriano Marques Neto e João Eduardo Queiroz, que mostram as várias concepçóes para, ao final, proporem seu conceito:

"Fixando nosso conceito em relação a esses termos, temos que: a planificação seria o processo pelo qual são definidos os pressupostos do planejamento; o planejamento é todo o arcabouço axiológico, conceitual e teórico voltado para a seleção de objetivos, fixação de metas e previsão e disposição de meios para efetivá-las. Já o instrumento jurídico-normativo que formaliza o planejamento, para que possa ser executado, é o plano". ${ }^{44}$

Outra expressão também associada ao planejamento é política pública, também carecedora de precisão em sua conceituação, mas cujas referências, no sentido de identificar melhor seu conteúdo, convêm mencionar.

A professora Maria Paula Dallari Bucci, seguramente a jurista que mais se aprofundou no tema, expõe a questão e permite identificar e relacionar os conceitos de política pública com os de planejamento e plano.

A autora define políticas públicas como "programas de ação governamental visando a coordenar os meios à disposição do Estado e as atividades privadas, para a realização de objetivos socialmente relevantes e politicamente determinados" ${ }^{45}$ mas reconhece que "política pública é uma locução polissêmica cuja conceituação só pode ser estipulativa”. ${ }^{46}$ Mostra que as políticas são "instrumentos de ação dos governos - o government by policies que desenvolve e aprimora o government by

43 SOUZA, Washington Peluso A. Primeiras linhas de direito econômico, p. 374.

44 MARQUES NETO, Floriano; QUEIROZ, João Eduardo Lopes. Planejamento, p. 685.

45 BUCCI, Maria Paula Dallari. Direito administrativo e politicas públicas, p. 241.

46 BUCCI, Maria Paula Dallari. Direito administrativo e políticas públicas, p. 251. 
law", de modo que a função de governar torna-se "o núcleo da ideia de política pública, redirecionando o eixo de organização do governo da lei para as políticas". ${ }^{47}$ Em seguida, evidencia essa proximidade entre a política pública e o plano. Reconhece que

"frequentemente as políticas públicas se exteriorizam através de planos (embora com eles não se confundam), que podem ter caráter geral, como o Plano Nacional de Desenvolvimento, regional, ou ainda setorial, quando se trata, por exemplo, do Plano Nacional de Saúde, do Plano de Educação etc. Nesses casos, o instrumento normativo do plano é a lei, na qual se estabelecem os objetivos da política, os instrumentos institucionais de sua realização e outras condiçôes de implementação".

E deixa claro que "a política é mais ampla que o plano e define-se como processo de escolha dos meios para a realização dos objetivos do governo, com a participação dos agentes púbicos e privados", de modo que a "política pública transcende os instrumentos normativos do plano ou programa”48 (grifo nosso).

Com efeito, vê-se que as políticas públicas transcendem não só o aspecto normativo, mas também a própria estrutura administrativa do Estado, pois se sobrepõe à organização federativa, uma vez que muitas delas - não seria desarrazoado dizer, a maioria - são realizadas em regime de cooperação federativa. E transcendem também a própria organização setorial da Administração Pública, por abrangerem várias vezes uma multiplicidade de órgãos integrantes de diversas áreas da administração, o que se constatará oportunamente, por ocasião da referência às políticas e agendas transversais. E a autora não deixa de ressaltar também que as políticas públicas não se limitam aos aspectos orçamentários, o que evidencia sua abrangência, indo além do planejamento orçamentário:

"A alocação de meios para as políticas públicas abrange possibilidades amplas e diversas, além dos recursos orçamentários. Os meios públicos disponíveis para a implementação de uma política pública podem compreender também créditos fiscais, empréstimos públicos, cessão de uso de áreas ou bens públicos e recursos humanos e materiais". ${ }^{49}$

E a questão se complexifica na medida em que o ordenamento jurídico não faz distinção clara entre essas expressões, que se encontram de forma bastante aleatória nos textos legais. Luiz Fernando Arantes Paulo exemplifica que as denominações política, plano e programa aparecem na Constituição em vários dispositivos

47 BUCCI, Maria Paula Dallari. Direito administrativo e politicas públicas, p. 252.

48 BUCCI, Maria Paula Dallari. Direito administrativo e politicas públicas, p. 259.

49 BUCCI, Maria Paula Dallari. Fundamentos para uma teoria jurídica das politicas públicas, p. 174. 
indicando tratar-se de casos de planejamento. Mostra que: “a expressão 'política' como forma de planejamento aparece em vinte e quatro dispositivos na Constituição Federal de 1988” (enumera no Quadro 1 da página 6); “entre os anos de 2000 e 2014, foram publicadas dezoito leis versando sobre políticas nacionais" (enumeradas no Quadro 2 da página 8); a "Constituição dispõe expressamente sobre planos como expressão do planejamento público”, conforme se vê em vários dispositivos, que enumera no Quadro 2 (página 11); também são numerosos os dispositivos da Constituição em que aparece a expressão "programa" como expressão do planejamento (conforme Quadro 5 da página 14); e, além dos programas que integram o plano plurianual e as leis orçamentárias, há muitos programas estabelecidos por leis específicas (exemplifica no Quadro 6, página 15). ${ }^{50} \mathrm{O}$ que se pode inferir é que a legislação trata de maneira pouco técnica a questão do planejamento e as várias expressões pelas quais ele se manifesta.

Mas o que importa, efetivamente, é identificar determinado fenômeno, como é o que ora se faz, e explicitar, da forma mais clara e precisa possível, a expressão utilizada para denominá-lo, dando-lhe os contornos de modo a permitir que o leitor possa compreender o objeto de estudo e suas limitações.

O planejamento orçamentário da Administração Pública aproxima-se ao conceito que Nazaré Cabral estabelece para programação. A autora, em obra de referência no tema, mostra haver dificuldades na distinção entre planejamento e programação, conceitos afins muitas vezes vistos como sinônimos. Traz ela considerações relevantes e interessantes, que merecem destaque e permitem um aprofundamento na tentativa de melhor esclarecer os conceitos. Ao relacionar a programação com o planejamento, mostra haver uma relação que se concretiza de diferentes formas. Diz ela: ${ }^{51}$

“i) A programação como elemento do planeamento, na medida em que aquele se decomponha e organize por programas e projetos. É neste sentido que se vem afirmando que, de um dado plano global, fazem parte programas sectoriais que dele constituem desagregações e especificações;

ii) a programação como componente técnica do planeamento, na medida em que este faça apelo a técnicas de programação (v.g. a construção de modelos de programação, que possam servir objectivos previsionais, de curto, médio e longo prazo). E concomitantemente; iii) a programação como processo de optimização do planeamento (v.g. a programação dinâmica)".

50 PAULO, Luiz Fernando Arantes. Os caminhos para os direitos sociais na Constituição Brasileira. Revista Brasileira de Orçamento Público, p. 4-24.

51 CABRAL, Nazaré da Costa. Programação e decisão orçamental. Da racionalidade das decisões orçamentais à racionalidade econômica, p. 46. 
E, mais adiante, ao estabelecer distinções entre conceitos: ${ }^{52}$

“vi) (...) se o horizonte temporal do planeamento económico é, no limite, o longo prazo, a programação apresenta predominantemente uma óptica temporal de curto prazo (ainda que, progressivamente, se tenha aproximado das técnicas de previsão de médio prazo, pensadas de início para os planos quadrienais ou quinquenais, ostentando uma característica de plurianualidade; vii) (...) o planeamento se apresenta como um "olhar" organizado sobre o futuro fixado num determinado momento, a programação é um processo contínuo de ir fazendo previsôes e comprovando a sua validade à medida que se vai consumando a respectiva implementação; (...) planeamento pressupōe (...) período temporal (...) previamente fixado e congelado, ao passo que a programação se baseia numa técnica flexível de deslize ao longo do tempo".

$\mathrm{Na}$ mesma linha, segue ao dizer que "Um elemento caracterizador da programação prende-se com o respectivo horizonte temporal. (...) A programação acolhe uma perspectiva que é fundamentalmente de curto (1 ano) e de médio prazos ( 2 a 5 anos)".53

Nazaré Cabral reconhece haver essa similaridade entre planejamento e o que ela denomina programação:

"Às vezes, a programação e o planeamento aparecem como sinónimos ou como conceitos afins; noutras ocasiōes, a programação surge como uma das formas de planeamento; noutras, como seu elemento integrante e, muito especialmente, não raro, como método ou técnica de planeamento". ${ }^{4}$

Justifica-se, por conseguinte, que tais conceitos não possam ser considerados precisos, admitindo-se estabelecer critérios próprios com os quais se possam construir expressões para delimitar adequadamente o objeto de estudo.

A ideia de programação que a citada autora nos dá, neste ponto, mostra uma aproximação bastante significativa com o sistema do ora denominado planejamento orçamentário da Administração Pública no Brasil de hoje, em que podemos identificar claramente a existência de um documento de caráter plurianual de médio prazo (atualmente quadrienal, período equivalente a um mandato), que é o Plano Plurianual, o de curto prazo, a Lei Orçamentária Anual, e a Lei de Diretrizes Orçamentárias, que, além de exercer a função de associar as previsões quadrienais do PPA às disposições anuais que constarão da LOA, a partir da Lei de Responsabili-

52 CABRAL, Nazaré da Costa. Programação e decisão orçamental. Da racionalidade das decisões orçamentais à racionalidade econômica, p. 153-155.

53 CABRAL, Nazaré da Costa. Programação e decisão orçamental. Da racionalidade das decisões orçamentais à racionalidade econômica, p. 175.

54 CABRAL, Nazaré da Costa. Programação e decisão orçamental. Da racionalidade das decisões orçamentais à racionalidade econômica, p. 39. 
dade Fiscal, passou a conter o Anexo de Metas Fiscais, com previsão das "metas anuais, em valores correntes e constantes, relativas a receitas, despesas, resultados nominal e primário e montante da dívida pública, para o exercício a que se referem e para os dois seguintes", deixando clara a implementação nos termos do que foi delineado pela autora citada, em um processo contínuo de previsões, com uso de uma técnica flexível, caracterizando um sistema de planejamento deslizante. ${ }^{55}$

O sistema de planejamento deslizante mostra-se ainda mais ajustável ao sistema orçamentário brasileiro se for considerada a necessidade de compatibilização federativa, especialmente porque, no País, atualmente, não há coincidência nos mandatos dos chefes dos poderes executivos e, por consequência, dos planos plurianuais. As eleiçôes dos prefeitos ocorrem no meio do mandato do presidente da República e dos governadores dos estados, de modo que os planos plurianuais federais e estaduais estão sempre em andamento quando têm início os planos plurianuais municipais, e, de outra parte, estão vigentes os planos plurianuais municipais quando surgem os planos plurianuais federais e estaduais. A existência de inúmeras políticas públicas em cooperação federativa e a necessidade de compatibilização das ações de todas as esferas de governo mostram a conveniência de sistemas de planejamento deslizante, que permitem coordená-las de forma mais eficiente e com maior segurança jurídica e previsibilidade.

O papel do PPA no ordenamento jurídico brasileiro como instrumento de programação plurianual das despesas, e, portanto, com claro viés orçamentário, é evidenciado por Ronaldo Garcia, estudioso do tema, ao discorrer sobre as funções do PPA:

"Como afirmado anteriormente, o PPA foi concebido pelos constituintes de 1987 como programação plurianual de despesas. O planejamento governamental está por ter sua organização formalizada, compatibilizando as diversas disposições encontradas na CF/88 com o que há de mais avançado em termos de planejamento estratégico público. Esta é a tarefa premente que vem sendo postergada, com grande prejuízo para os governantes, o povo brasileiro e a própria democracia. Afinal, é direito do cidadão saber por quais caminhos e para qual futuro o país está sendo conduzido. E isto devem mostrar o programa do governo e o plano estratégico de desenvolvimento. $\mathrm{O}$ PPA e o OGU seriam apenas a expressão físico-financeira dos aspectos materiais dos planos de desenvolvimento". ${ }^{56}$

55 Ou "rolante", segundo parte dos autores, como se verá oportunamente no tópico 3.2 - "Planejamento deslizante”, p. 195.

56 GARCIA, Ronaldo Coutinho. PPA: o que não é e o que pode ser. In: CARDOSO JR., José Celso; CUNHA, Alexandre dos Santos (Org.). Planejamento e avaliação de políticas públicas, p. 452 . 
E pondera, ainda, sobre a infrutífera e a inviável possibilidade de fazer com que o PPA seja um instrumento não de natureza orçamentário-financeira, mas de planejamento estratégico governamental:

"O PPA 2012-2015 reincidiu na vã expectativa de transformar instrumento de natureza orçamentário-financeira em guia para a condução estratégica do governo. Isto o PPA não poderá ser, a menos que os artigos 21, 165 e 174, da CF/88, sejam profundamente transformados, mediante emenda constitucional, dando lugar ao que seria um sistema de planejamento estratégico governamental" ${ }^{57}$

Há que se reconhecer, como se verá em outros trechos do trabalho, que, não obstante o aperfeiçoamento das técnicas de previsões e cálculos, não se mostra efetivamente viável a existência de planejamento orçamentário da Administração Pública para períodos de longo prazo. O planejamento orçamentário pressupõe uma razoável precisão na determinação dos montantes que serão destinados para as atividades governamentais, para as quais deve haver a fixação de resultados e metas quantificáveis, a fim de que existam dados objetivos nos quais a Administração Pública possa se basear para conduzir-se de forma segura, coordenada e coerente, o que só é viável a curto e médio prazos.

Concepçôes interessantes encontramos em Premchand, que distingue "substantive planning" de "fiscal planning", deixando entrever que o primeiro tem características próprias do "planejamento econômico governamental” e o segundo do planejamento orçamentário da Administração Pública:

"in general planning is of two types - substantive planning and fiscal planning. Substantive planning, which is also known as development planning, involves the planning of societal goals and objectives and the mobilizations of natural, human, and financial resources needed to their achievement. Fiscal planning, which is narrower in scope and is one of the instruments of substantive planning, consists of planning future budgets - current and future budget decisions, the implications of financing, and the methods of obtaining the necessary resources and allocating them in accordance with overall national goals". ${ }^{58}$

Em outras palavras, temos a ideia de "substantive planning" como um conceito de planejamento do desenvolvimento coordenando os recursos naturais, humanos e financeiros para atingir os objetivos e metas da sociedade, e a de "fiscal planning", para compreender um planejamento de pretensōes mais restritas, sendo instrumento do "substantive planning", para viabilizá-lo financeiramente, alocando os meios e recursos nos orçamentos para alcançar os objetivos estabelecidos.

57 GARCIA, Ronaldo Coutinho. PPA: o que não é e o que pode ser, p. 452.

58 PREMCHAND, A. Government budgeting and expenditure controls. Theory and practice, p. 176. 
O autor mostra ainda a intrínseca e indissociável relação entre o planejamento e o orçamento, deixando claro que o planejamento governamental se mostra essencial para determinar os objetivos nacionais e os meios para alcançá-los, fazendo dos planos e orçamentos atos de um mesmo processo. Orçamento sem planejamento deixa de ser um plano de ação governamental, e planos sem correspondência no orçamento têm pouca validade, diz ele com propriedade. ${ }^{59}$

A concepção de Medium-term Expenditure Framework (MTEF) também se aplica à ideia de planejamento orçamentário da Administração Pública, admitindo-se, como já exposto, ser um instrumento de planejamento para o médio e curto prazos. Surgido na Austrália, o MTEF “is an arrangement in which annual budget decisions are made in terms of aggregate or sectoral limits on expenditures for each of the next three to five years", na sucinta e precisa definição de Allen Schick. ${ }^{60}$ Como destaca o mesmo autor, é um importante instrumento para promover a disciplina fiscal e facilitar a realocação de recursos conforme as prioridades estratégicas fixadas pelo governo, uma vez que, havendo as estimativas financeiras dos programas prioritários por prazos maiores, permite analisar a consistência de eventuais alteraçôes com as prioridades governamentais. ${ }^{61}$

Luís Cabral de Moncada é quem melhor estabelece distinção que se ajusta ao que se procura demonstrar, evidenciando haver uma relação entre o planejamento econômico e o que ele chama de "planificação financeira", cuja delineação do conceito bem se aproxima do que se está denominando planejamento orçamentário da Administração Pública.

Ao mostrar que existe uma relação de subordinação do orçamento ao plano, estabelece a noção de planificação financeira, a qual, segundo o autor,

59 "Planning, in its simplest form and as it came to be used in governments, is considered as organized, rational thought that is essential for a determination of the national objectives, the instruments to be used, and needed inputs. In more diversified forms, planning is considered as a projected course of action, as a means of reaching an end, as a special process for reaching a rational decision, as full utilization of all the materials of the community, as an art, and as a process of preparing a set of decisions for action in the future directed at achieving goals by optimal means. Budget and plans are, therefore, facts of the same process. Budgeting without planning ceases to be a plan of action, and plans that do not have a realistic recognition of the budgetary constraints have little functional value. Each disciplines the other, and the end products should ideally bear the imprint of both" (PREMCHAND, A. Government budgeting and expenditure controls. Theory and practice, p. 188).

60 SCHICK, Allen. Does budgeting have a future? OECD Journal on Budgeting, p. 11.

${ }^{61}$ SCHICK, Allen. Does budgeting have a future? p. 27-28. 
"pretende justamente cobrir a realidade das relações entre o plano e o orçamento; é uma noção intermédia entre os conceitos de plano e de orçamento e que traduz a adequação do orçamento e do plano. $\mathrm{Na}$ medida em que o orçamento fixa planos previsionais de despesas, de modo a conformar-se ao plano económico geral, está a fazer-se planificação financeira. Estes planos previsionais, como já se viu, traduzem-se normalmente em programas, em agrupamentos de despesas segundo critérios teleológicos, produto de uma mais apurada racionalidade da decisão económica dos poderes públicos".

E conclui, em palavras que se encaixam com perfeição à argumentação que se vem desenvolvendo, que "A planificação financeira é assim uma parte da planificação econômica nacional, precisamente a parte que exprime em termos financeiros, no quadro do orçamento, as finalidades prospectivas da planificação económica nacional" (grifo nosso). ${ }^{62}$

Vê-se ser perfeitamente admissível, e compreensível de forma suficientemente clara, a concepção de planejamento com esses dois significados e respectivos enfoques, a saber, e em parte reitero e ratifico o que já foi exposto: a existência de um planejamento econômico governamental, com maior densidade axiológica, que volta suas preocupações à definição dos rumos do Estado, com conteúdo de caráter essencialmente nacional; e um planejamento orçamentário da Administração Pública, cujas preocupações são de caráter basicamente instrumental, voltadas a materializar as decisões políticas em medidas concretas que permitam conduzir a Administração Pública de forma coesa e coordenada em direção aos rumos estabelecidos. ${ }^{63}$

Várias razões tornam indispensável que o planejamento - que, em uma primeira dimensão, tem este viés político - assuma um caráter técnico, com clareza e precisão na descrição das ações governamentais nas quais se desdobrarão as políticas públicas definidas, e a respectiva associação a valores monetários precisos, com objetivos, resultados e metas. É o caso, por exemplo, da necessidade de implemen-

62 MONCADA, Luís S. Cabral de. A problemática jurídica do planeamento económico, p. 112. Em sentido semelhante: Perspectivas do novo direito orçamental português. In: MONCADA, Luís S. Cabral de. Estudos de direito público, p. 90-92.

63 Em sentido que se assemelha ao que foi exposto, no âmbito do direito português, expõe Cabral de Moncada: "Pode, pois concluir-se que as relaçôes entre o orçamento e o planeamento econômico são a expressão sintetizada do carácter instrumental do primeiro relativamente ao segundo verdadeiramente o núcleo da concepção da actividade financeira que a Constituição recebe. Muito embora a subordinação do orçamento ao planeamento teria sido desvalorizada depois da última revisão constitucional, como já se disse, a concepção constitucional continua a ser aquela" (Perspectivas do novo direito orçamental português, p. 92). 
tação de um sistema eficaz de fiscalização da atividade financeira, que depende de informações precisas e objetivas, sem as quais fica em boa medida prejudicada a possibilidade de confrontar o que vem sendo feito com o que foi estabelecido. Isso também se aplica à transparência da gestão financeira do Estado, que exige informações com os mesmos requisitos, sem os quais não se viabiliza. E não há como se restringi-las às atividades financeiras de curto prazo, com a disponibilização de dados voltados tão somente ao acompanhamento da Lei Orçamentária Anual. A sociedade hoje não prescinde de informações que permitam acompanhar a evolução da atividade financeira do setor público ao menos no horizonte temporal de médio prazo, exercendo a fiscalização e se conscientizando de modo a permitir uma participação mais efetiva por ocasião das definiçôes dos rumos que o Estado seguirá, a longo e médio prazos.

Não se deve deixar de lado, e é preciso reconhecer como igualmente importante, a existência de planejamentos de prazo mais longo, indispensáveis para que a Administração Pública possa ter um rumo nos horizontes temporais mais distantes do que os atuais documentos que permitem especificações de médio prazo. No entanto, as tentativas já realizadas nesse sentido, o que será mais bem abordado no item 1.4 - "Planejamento do setor público | Breve histórico e evolução", ainda não se mostraram plenamente viáveis, com instrumentos capazes de especificar detalhes suficientes a produzir documentos verdadeiramente orçamentários. Nesses casos, em geral o que se permite fazer são documentos, eventualmente concretizados em normas, com proposições indicativas, sem a fixação de valores exatos, e com resultados e metas mais abrangentes, que possibilitam mostrar a direção a seguir, caracterizando um planejamento econômico, mas não orçamentário.

Importa destacar o caráter instrumental do planejamento orçamentário da Administração Pública, que compreenderá um conjunto de técnicas e instrumentos que viabilizarão a implementação das diretrizes e políticas gerais do Estado, estabelecidas na Constituição em uma primeira dimensão e detalhadas em outras normas infraconstitucionais, entre as quais as que veiculam aspectos do planejamento econômico governamental. ${ }^{64}$ Não que se possa, ressalte-se, determinar uma separação absolutamente clara, de modo a excluir as próprias normas de planejamento orçamentário da Administração Pública como delineadoras dessas

64 Veja-se nesse sentido as palavras de Cabral de Moncada ao tratar do tema: "Pode pois concluir-se que as relações entre o orçamento e o planeamento econômico são a expressão sintetizada do carácter instrumental do primeiro relativamente ao segundo verdadeiramente o núcleo da concepção da atividade financeira que a Constituição recebe" (Perspectivas do novo direito orçamental português, p. 92). 
diretrizes e políticas gerais do Estado, como pode ocorrer, e efetivamente por vezes ocorre, em muitas situações. A falta de uma estruturação e de um claro delineamento entre as várias funções que assume o planejamento e as respectivas normas que o veiculam impedem essa precisão e clareza. No entanto, é possível compreender, nos termos da distinção que ora se procura tornar mais nítida, essa função essencialmente instrumental que assume o planejamento orçamentário, como sistema de normas voltado a viabilizar a implementação, nos entes da Federação, por meio da inserção nas leis orçamentárias, dessas diretrizes e políticas gerais do Estado.

O estudo do planejamento orçamentário, em função de seu conteúdo, na forma do que foi exposto, guarda estreita correlação com a Administração Pública, e ao longo deste trabalho esta inter-relação se mostrará sempre presente. Formas e técnicas de planejamento, objeto de intensos estudos no âmbito da Administração Pública, ocuparão boa parte das questóes que integrarão os desafios a serem vencidos, e, no mais das vezes, sempre haverá a preocupação de voltar a atenção aos aspectos jurídicos que se mostrarem presentes, de modo que se mantenha o foco no âmbito do Direito Financeiro, respeitando-se a já reconhecida multidisciplinariedade do tema abordado.

\subsection{PLANEJAMENTO DO SETOR PÚBLICO | BREVE HISTÓRICO E EVOLUÇÃO}

O estudo do planejamento orçamentário da Administração Pública no Brasil não prescinde de uma análise da evolução histórica do planejamento do setor público, o que permitirá compreendê-lo melhor. ${ }^{65}$

E, nesse caso, não há como dissociar as diversas concepções que ora se procura estabelecer do planejamento, de modo que essa abordagem histórica forçosamente abrangerá o planejamento governamental em sua acepção mais ampla, chamando-se a atenção e dando-se maior ênfase, quando for o caso, para os aspectos mais específicos do objeto de estudo desta tese.

Não há como se determinar com precisão a origem do planejamento, nem identificar exatamente qual seja o primeiro ato que possa ser reconhecido como o marco inicial deste instituto.

65 Algumas das referências deste item encontram-se parcialmente em textos de minha autoria, mencionados nas Referências ao final - "Aspectos jurídicos do planejamento pelo setor público”, especialmente nas páginas 498-505 e “O plano plurianual - PPA”, notadamente nas páginas 323-325, não sendo usadas aspas nas eventuais reproduções em virtude de ajustes, atualizações e modificações nos textos. 
A primeira experiência de planejamento, relata Eros Grau, em sua obra que é referência no tema do planejamento econômico, deu-se em 1921, com a criação, na Rússia soviética, da GOSPLAN, órgão estatal responsável pelo planejamento governamental, e pela elaboração dos planos que conduziriam a economia soviética nos anos subsequentes, a partir de 1928, quando se implantou o primeiro plano quinquenal. ${ }^{66}$

Nazaré Cabral registra que na economia alemã de finais do século XVIII e princípios do século XIX encontram-se referências à planificação estatal, mas efetivamente somente a partir da experiência soviética, no início do século XX, é que "se assistiu verdadeiramente à criação de uma estrutura planificada de organização e gestão da economia". ${ }^{67}$

O planejamento instituído à época nos países ditos socialistas tem características de integralidade e imperatividade, tornando o Estado verdadeiramente substituto do mercado e abrangendo a economia como um todo, compreendendo o controle e a direção dos processos de produção, repartição, acumulação e consumo. ${ }^{68}$

Já o planejamento dos países capitalistas tem caráter essencialmente intervencionista, interferindo na liberdade, mas sem suprimi-la. ${ }^{69}$

Nos países capitalistas, o planejamento se desenvolveu mais intensamente a partir da década de 1930, com o início da crise econômica mundial e a necessidade de intervenções econômicas substanciais, a fim de promover a recuperação da economia. Destacam-se nesse período, registra o mestre, o Plano Tardieu, em 1928, na França, e o Plano Marquel, em 1933. ${ }^{70}$ Nos Estados Unidos, nesse mesmo ano, a criação do Tennessee Valley Authority e, na Alemanha, em 1936, o Plano de Quatro Anos. A importância do planejamento se intensifica no período subsequente à Segunda Guerra Mundial, passando a ser adotado de forma generalizada pelos países capitalistas, que passam a reconhecer seus métodos como "imprescindíveis à realização dos fins do desenvolvimento socioeconômico" e "imperiosa exigência do processo de desenvolvimento econômico", perdendo a conotação de instituto ligado a qualquer ideologia. ${ }^{71}$

66 GRAU, Eros. Planejamento econômico e regra jurídica, p. 11.

67 CABRAL, Nazaré da Costa. Programação e decisão orçamental. Da racionalidade das decisões orçamentais à racionalidade econômica, p. 73.

68 CABRAL, Nazaré da Costa. Programação e decisão orçamental. Da racionalidade das decisões orçamentais à racionalidade econômica, p. 74-75.

69 Nesse sentido: GRAU, Eros. Planejamento econômico e regra jurídica, p. 38.

70 GRAU, Eros. Planejamento econômico e regra jurídica, p. 11.

71 GRAU, Eros. Planejamento econômico e regra jurídica, p. 12. 
Mais recentemente, houve um impulso no planejamento orçamentário da Administração Pública motivado pelos países europeus sujeitos às exigências das restrições financeiras impostas pela comunidade europeia, o que os forçou a adotar planejamentos plurianuais de médio prazo, voltados a alcançar um equilíbrio sustentável em suas finanças públicas. $\mathrm{O}$ caso francês evidencia isso de modo bastante claro, conforme registra Michel Bouvier, especialmente em função da adoção da nova Lei de Finanças (LOLF - Loi Organique n. 2001-692, du $1^{\circ}$ août 2001, relative aux Lois de Finances), substituindo o texto vigente em 1959, promovendo importante reforma no sistema orçamentário francês, em consonância com a nova redação do art. 34 da Constituição, introduzida pela revisão constitucional de 23 de julho de 2008, o que deu origem ao primeiro orçamento plurianual trienal, para o período de 2009 a 2011 ("des lois de programmation déterminent les objectifs de l'action de l'État. Les orientations pluriannuelles des finances publiques sont définies par des lois de programmation. Elles s'inscrivent dans l'objectif d'équilibre des comptes des administrations publiques"). ${ }^{72}$

No Brasil, em linhas gerais, podem ser identificadas quatro fases na evolução do planejamento governamental, como sintetizado por José Luiz Pagnussat, e que será mais bem analisado a seguir, ainda que sucintamente:

"a primeira, orçamentária, de elaboração de diagnósticos e de estruturação das bases do chamado Estado nacional-desenvolvimentista, nos anos 30 e 40; a segunda, desenvolvimentista, com a implementação de planos nacionais voltados para a industrialização e consolidação da infraestrutura; a terceira, com o objetivo de estabilização econômica, nos anos 80 e início dos anos 90 ; e a quarta, de retomada do planejamento, com os avanços metodológicos na elaboração do PPA, a partir do final dos anos $90 "{ }^{73}$

Não é simples identificar como e quando se iniciou o planejamento no Brasil.

72 “D'autre part, et surtout, la contrainte européenne a engagé les finances de l'État français dans une logique et un processus pluriannuels. Les exigences du Pacte de stabilité et de croissance liées à la mise en œuvre de la monnaie unique ont imposé aux États membres de l'Union européenne d'élaborer des programmes pluriannuels de finances publiques communiqués à la Commission et au Conseil, et définissant des objectifs à moyen terme sur lesquels les États s'engagent. Enfin, des raisons liées à la nécessité de parvenir à atteindre l'équilibre des comptes publics ont certainement joué un rôle essentiel dans la mise en œuvre concrète de procédures visant à instituer de manière durable un dispositif suffisamment sophistiqué pour que soit élaborée une programmation à moyen terme des finances publiques" (BOUVIER, Michel. Programmation pluriannuelle et équilibre des finances publiques: les conditions du succès. Revue Française de Finances Publiques, p. 1).

73 PAGNUSSAT, José Luiz. Introdução. In: GIACOMONI, James; PAGNUSSAT, José Luiz. Planejamento e orçamento governamental, p. 26. 
No início da história constitucional brasileira, não se contemplavam a concepção nem claros instrumentos para o planejamento orçamentário. $\mathrm{Na}$ Constituição de 1824, o art. 172 tratava, em breves linhas e de forma genérica, sobre o orçamento público: era de competência do Ministro da Fazenda, que recebia de outros Ministros os orçamentos referentes às respectivas pastas, a apresentação da peça orçamentária à Câmara dos Deputados. Havia a necessidade de apresentação tanto de um "balanço" das receitas e despesas do ano anterior como as do ano subsequente, em uma nítida lógica de orçamento incremental. $\mathrm{O}$ dispositivo pátrio é muito semelhante a um artigo (art. 227) contido na primeira Constituição portuguesa, a Constituição de 23 de setembro de 1822.

Eros Grau cita o Decreto n. 524, de 1890, como o marco originário do nosso planejamento, pois tornou obrigatória a inclusão de todas as estradas em um "plano geral de viação", que só veio a surgir 44 anos após. ${ }^{74}$

A Constituição de 1891, igualmente, não trouxe inovações no que concerne à sistemática do planejamento governamental na esfera constitucional, o que somente seria introduzido no século seguinte com a Constituição de 1934 e a incorporação das recentes técnicas de planejamento do início do século XX. Passaram a ser competências privativas do Congresso Nacional orçar a receita e fixar a despesa (art. 34, $\$ 1^{\circ}$ ), não sendo possível às leis orçamentárias conter disposições estranhas à previsão de receitas ou fixação de despesa (art. 34, $\$ 1^{\circ}$ ), constitucionalizando o princípio da exclusividade e representando a evolução do direito financeiro à época com o fim dos "orçamentos rabilongos".

Uma das primeiras medidas em prol de uma ação governamental planejada começou a se dar ainda na República Velha. É o caso do Programa de Estabilização de Joaquim Murtinho, Ministro da Fazenda entre 1888 e 1902, e as missóes inglesas, como as de Edwin Montagu (1923) e de Niemayer, responsável pelo célebre Niemeyer Report, na década de 1930, que dedicava boa parte de suas páginas para criticar o sistema de finanças públicas no Brasil. ${ }^{75}$

$\mathrm{Na}$ Constituição de 1934, passou-se a imprimir relevância aos planos setoriais, em uma forma ainda precária de planejamento governamental por planos. A Constituição de 1934 estabeleceu a responsabilidade pela elaboração de diversos planos governamentais, o que se pode vislumbrar como uma primeira tentativa de traçar um planejamento governamental constitucional no País. É importante registrar,

74 GRAU, Eros. Planejamento econômico e regra jurídica, p. 128.

75 BAER, Werner. A economia brasileira, p. 62 e IANNI, Octavio. Estado e planejamento econômico no Brasil, p. 55. 
nesse contexto, os seguintes planos: a) Plano Nacional de Viação Férrea e o de Estradas de Rodagem (competência privativa da União no art. 5º, IX); b) Plano Nacional de Educação (competência da União, no art. 150, e específica do Conselho Nacional de Educação, no art. 152), com a competência privativa para traçar as diretrizes da educação nacional (art. 5०, XIV); c) Plano para Defesa contra os Efeitos das Secas nos Estados do Norte (art. 177, inclusive com a instituição de uma despesa mínima obrigatória); d) Plano para Reconstrução Econômica Nacional (art. 16 das Disposições Transitórias).

A Constituição também já definia uma distribuição de competências que obrigava a um planejamento setorial mínimo, como no caso do art. $5^{\circ}$, VIII, que estabelecia como competência privativa da União explorar ou dar em concessão os serviços de telégrafos, radiocomunicação e navegação aérea, além das vias férreas que servissem para conectar os portos marítimos a fronteiras nacionais, ou fossem além do limite dos Estados. Outro exemplo de que a distribuição de competências requereria planejamentos setoriais no âmbito federal foi a instituição de competência privativa da União para legislar sobre determinados temas. Dessa forma, para citar alguns exemplos, o art. 5\%, XIX, $e$, destaca o regime de portos e navegação de cabotagem - assegurando a exclusividade aos navios nacionais quanto a mercadorias, no caso da cabotagem -, e a alínea $j$ inscreve as riquezas do subsolo, de mineração, metalurgia, águas, energia hidrelétrica, florestas, caça e pesca e a sua exploração.

A inserção de competências concorrentes também obrigaria a uma coordenação interfederativa, o que originaria, décadas mais tarde, a grande dificuldade de um planejamento intergovernamental em um sistema federativo como o brasileiro. $\mathrm{O}$ art. 10 descreve como competências concorrentes da União e dos Estados a saúde (inc. II) e a difusão da instrução pública em todos os graus (inc. VI).

Eros Grau dá destaque à inclusão, na Constituição de 1934, em seu art. 5º, IX, do dispositivo atribuindo à União a competência para estabelecer o Plano Nacional de Viação Férrea e o de Estradas de Rodagem, e no art. 16 das disposiçōes transitórias a determinação para a elaboração de um plano de reconstrução econômica nacional, que só se materializou em 1939, já sob a égide da Constituição de 1937, com o Plano Especial de Obras Públicas e Aparelhamento da Defesa Nacional. ${ }^{76}$

Houve importante avanço na Constituição de 1937 no art. 67, ao prever um Departamento Administrativo junto à Presidência da República. A criação do De-

76 GRAU, Eros. Planejamento econômico e regra jurídica, p. 130. 
partamento Administrativo do Serviço Público (DASP), pelo Decreto-lei n. 579, de 30 de julho de 1938, é fato da maior relevância no período para o planejamento orçamentário da Administração Pública, tendo sido órgão responsável pela intensificação da modernização da Administração Pública na época, e, nessa linha de ação, implementando medidas para fazer dos orçamentos públicos instrumentos voltados ao planejamento das atividades governamentais. É relevante no DASP a criação das Comissões de Eficiência, consoante regulamentado no Capítulo II do referido Decreto-Lei. O conceito de eficiência, uma das grandes inovações conceituais do Direito Financeiro naquele século, seria posteriormente introduzido na Constituição de 1988 com a Emenda Constitucional n. 19, de 1998.

Seguiu-se o Plano de Obras e Equipamentos (POE), de 1943, que, tal como o anterior, tinha a natureza de um verdadeiro orçamento plurianual de cinco anos, concentrando suas preocupações não em previsão de comportamentos econômicos e sociais futuros, mas essencialmente na destinação de recursos orçamentários para despesas específicas, especialmente no setor de indústrias de base e obras de caráter civil. ${ }^{77}$ Interessante observar que "para sua execução foi previsto um estilo específico de dualidade orçamentária, que, na prática, consagrava a divisão entre orçamentos de inversão e de custeio", que, segundo a Comissão de Orçamento à época, permitia maior flexibilidade contábil, reduzindo a burocracia para a construção das grandes obras; neste plano, o relacionamento entre orçamento e plano dava-se por meio do chamado orçamento especial, contabilizando-se créditos aos organismos públicos encarregados pelo Tribunal de Contas da União, conforme estabelecido pelo Ministério da Fazenda, que controlava a execução financeira e a distribuição dos recursos. ${ }^{78} \mathrm{O}$ plano acabou tendo a duração de dois anos, sendo alterado em 1945 e extinto em $1946 .^{79}$

A Constituição de 1946 pode ser considerada um marco temporal, sobretudo por sua concepção em um momento imediatamente posterior ao fim da Segunda Guerra Mundial, importante marco histórico para o planejamento da ação governamental no mundo. André Castro Carvalho demonstra que o planejamento da infraestrutura está intimamente relacionado com a evolução do conceito militar pós-Segunda Guerra Mundial. ${ }^{80}$ De fato, o planejamento setorial nos Estados Uni-

77 GRAU, Eros. Planejamento econômico e regra jurídica, p. 131.

78 SOUZA, Nelson Mello e. O planejamento econômico no Brasil: considerações críticas. Revista de Administração Pública, p. 1678.

79 SOUZA, Nelson Mello e. O planejamento econômico no Brasil: considerações críticas, p. 1679.

80 CARVALHO, André Castro. Direito da infraestrutura: perspectiva pública, p. 82 e p. 91-95. 
dos com o New Deal teve forte inspiração na concepção militar vigente da época. Nesse sentido, explica Octavio Ianni:

"É muito provável que a técnica de planejamento, enquanto instrumento de política econômica estatal, tenha começado a ser incorporada pelo poder público, no Brasil, durante a Segunda Guerra Mundial. Ao menos, foi nessa época que a planificação passou a fazer parte do pensamento e da prática dos governantes, como técnica 'mais racional' de organização das informações, análise de problemas, tomada de decisōes e controle da execução de políticas econômico-financeiras". ${ }^{81}$

A Constituição de 1946 resgata, no âmbito constitucional, os planos veiculados na Constituição de 1934, sendo pertinente mencionar: a) Plano Nacional de Viação (art. 5º, X); b) Planos de Colonização e de Aproveitamento das Terras Públicas, dentro da política agrária (art. 156); c) Plano de Defesa contra os Efeitos da Seca no Nordeste (art. 198); d) Plano de Valorização Econômica da Amazônia (art. 199); e) Plano de Aproveitamento Total das Possibilidades Econômicas do Rio São Francisco e seus afluentes, a ser elaborado no prazo de 20 anos da promulgação da Constituição (art. 29 do Ato das Disposiçōes Constitucionais Transitórias).

Em 1950, é publicada a lei que institui um dos mais relevantes marcos no planejamento governamental no Brasil, que foi o Plano SALTE (sigla identificadora das principais áreas priorizadas pela ação do plano: saúde, alimentação, transporte e energia), para o período de 1950 a 1954, que merece destaque no aspecto jurídico por ser "a primeira experiência brasileira de planejamento a lançar mão, igualmente, das normas de planos impositivos e indicativos" ${ }^{82}$ Foi também importante no sentido de cumprir "a função de auxiliar e precisar a consciência crítica do desenvolvimento, indicando os problemas e opções possíveis", tendo, porém, fracassado como plano, conforme posiciona Nelson Mello e Souza: "O Plano Salte, como plano constituiu-se numa realidade puramente retórica, sem nenhuma eficácia executiva, sendo talvez o mais espetacular desastre das tentativas de planificação no Brasil", ${ }^{3}$ evidenciando, entre as várias debilidades do plano, as questôes orçamentárias, como a imprecisão no estabelecimento de fontes de recursos e a falta de relacionamento entre a administração orçamentária com as necessidades de recursos no tempo certo, além da falta de coordenação e controle físico e financeiro de execução do plano. ${ }^{84}$

\footnotetext{
81 IANNI, Octavio. Estado e planejamento econômico no Brasil, p. 54.

82 GRAU, Eros. Planejamento econômico e regra jurídica, p. 137.

83 SOUZA, Nelson Mello e. O planejamento econômico no Brasil: considerações críticas, p. 1681.

84 SOUZA, Nelson Mello e. O planejamento econômico no Brasil: considerações críticas, p. 1683.
} 
O Plano SALTE foi criticado por ter sido pouco foi executado na prática. Octavio Ianni menciona que

"O Plano SALTE foi uma tentativa de coordenação dos gastos públicos, tomando por base projeçôes relativas a um período de cinco anos. Era principalmente uma soma de sugestões apresentadas pelos diferentes ministérios do Governo Federal, e coordenadas - em termos administrativos e contábeis - pelo Departamento Administrativo do Serviço Público (DASP). Além disso, a despeito de ter sido incorporado à proposta orçamentária de 1949, não se aplicou senão em parte. Em 1952, o Plano foi praticamente abandonado. (...) Entretanto, como instrumento de ação governamental, o Plano era descoordenado e divorciado da realidade. Estas, também, são razões por que a maioria dos seus objetivos não pôde ser realizada". ${ }^{85}$

O Plano SALTE exibia semelhanças e diferenças com o recente Programa de Aceleração do Crescimento (PAC). Uma diferença fundamental, entretanto, é que o Plano SALTE foi aprovado por Lei, a Lei Ordinária n. 1.102, de 18 de maio de 1950, ao passo que o PAC, conforme será abordado, foi instituído por decreto autônomo.

A relação de governança interfederativa já se exibia no SALTE, tendo sido replicada posteriormente no PAC, por meio do parágrafo único do art. $1^{\circ}$, o qual estabelece que o Poder Executivo "promoverá entendimentos e firmará acordos" com os governos subnacionais para que sejam coordenadas as atividades relacionadas com o SALTE.

$\mathrm{O}$ art. 14 exibe uma característica que foi reaproveitada posteriormente pelo PAC: o estabelecimento de uma margem de preferência de produtos nacionais sobre estrangeiros para alguns setores industriais, a fim de estimular o desenvolvimento econômico setorial. ${ }^{86}$

Outra semelhança com o PAC é a crítica feita pela doutrina no sentido de que o SALTE não foi oriundo de um diagnóstico econômico da realidade nacional, ou seja, "não foi o resultado de uma interpretação de conjunto e interativa dos problemas econômicos e financeiros do País" ${ }^{87}$

$\mathrm{Na}$ história do planejamento no Brasil, há que se fazer referência àqueles que foram fatos e normas representativos do avanço na implementação de uma cultura de planejamento que hoje se solidifica de forma mais clara.

85 IANNI, Octavio. Estado e planejamento econômico no Brasil, p. 101.

86 "Art. 14. Na execução do Plano SALTE, o Poder Executivo, a fim de estimular a indústria nacional, dará preferência, em igualdade de condições técnicas, aos equipamentos produzidos no País, facilitando e fomentando, sempre que técnica, e economicamente indicada, a criação de novos setores industriais para a fabricação dêles."

87 IANNI, Octavio. Estado e planejamento econômico no Brasil, p. 104. 
A Comissão Mista Brasil-Estados Unidos, em 1951, no governo Getúlio Vargas, vinculada ao plano norte-americano de ajuda a países subdesenvolvidos, influenciou na criação do Banco Nacional de Desenvolvimento Econômico (BNDE), ocorrida em 1952, órgão de grande relevância nos anos subsequentes como responsável pelo fomento do desenvolvimento nacional.

O Programa de Metas no governo Juscelino Kubitschek, para o período de 1956 a 1960, elaborado com base em relatórios da citada comissão e em estudos do grupo BNDE-CEPAL, foi relevante para o desenvolvimento do País em várias áreas, com destaque para as de energia, transporte, indústrias siderúrgicas, de cimento e papel, e as produtoras de equipamentos no ramo automobilístico, naval e de bens de capital, além da construção da cidade de Brasília. ${ }^{88}$ Vê-se ter havido preocupação com as questōes orçamentárias, ${ }^{89}$ mas não sem destaque no aspecto jurídico, por representar essencialmente um conjunto de objetivos setoriais alinhados em trinta metas, com natureza essencialmente política e de pouco caráter vinculativo, sem se fundar em atos normativos, como observa Eros Grau. ${ }^{90}$ Não teve as características de um plano econômico nacional, mas sim de um "conjunto de objetivos setoriais a serem atingidos pelo setor público federal e pelo setor privado", evidenciando falta de integração instrumental e executiva, sem harmonia lógica entre os instrumentos de política econômica e sem uma organização da Administração Pública adequada às necessidades de uma administração planificada, o que contribuiu para acelerar o processo inflacionário e resultou em desequilíbrio no atingimento das metas, sendo algumas superadas, e outras descumpridas, ${ }^{91}$ critica Nelson Souza. Gilberto Bercovici ressalta aspectos positivos, mostrando que, "apesar de não ter sido propriamente um plano global, o Plano de Metas foi a primeira experiência efetiva de planejamento no Brasil, dando sentido de unidade a todos os projetos e programas setoriais nele previstos". E destaca um aspecto bastante interessante - sua implementação por meio do que se pode chamar de verdadeira "administração paralela", tendo em vista a inadequação da máquina

88 GRAU, Eros. Planejamento econômico e regra jurídica, p. 138-139; BRASIL. Ministério do Planejamento, Orçamento e Gestão. Secretaria de Planejamento e Investimentos Estratégicos. O desafio do planejamento governamental, p. 12.

89 Valores, porcentuais e fontes dos recursos dos financiamentos das metas são descritos, ainda que de forma geral, no relatório publicado em 1958 (BRASIL. Presidência da República. Programa de Metas do Presidente Juscelino Kubitschek. Estado do Plano de Desenvolvimento Econômico em 30 de junho de 1958, p. 9-11).

90 GRAU, Eros. Planejamento econômico e regra jurídica, p. 139.

91 SOUZA, Nelson Mello e. O planejamento econômico no Brasil: consideraçôes críticas, p. 1691-1692. 
administrativa, "composta por uma estrutura ultrapassada, com superposição de competências e definição de políticas conflitantes", de modo que "os órgãos responsáveis pela formulação e execução do Plano de Metas foram superpostos ao sistema administrativo tradicional", o que se refletiu, inclusive, no aspecto financeiro, tendo o BNDE assumido o papel de coordenar os programas governamentais, vinculando recursos públicos, por meio de empréstimos, para os investimentos nos setores estratégicos. ${ }^{92}$

A criação do Ministério do Planejamento, em 1961, no governo João Goulart, comandado por Celso Furtado, evidenciou na Administração Pública a importância do planejamento, que passou a ter um ministério especificamente voltado a cuidar do tema. Nesse período, foi elaborado o Plano Trienal de Desenvolvimento Econômico e Social, em 1962, para o período de 1963 a 1965, que trouxe importantes propostas de reformas nas áreas econômica e social, com características de um plano econômico global, sem detalhamento orçamentário, mas não chegou a ser efetivamente implementado. Uma tentativa frustrada que não saiu do papel, nas palavras de Nelson Mello e Souza, prejudicada, entre outras razóes, pela instabilidade política e crise econômica da época, ${ }^{93}$ sendo de qualquer forma relevante em termos teóricos, pelo destaque dado à função planejadora do Estado.

A Lei n. 4.320, de 17 de março de 1964, estatuiu "normas gerais de direito financeiro para elaboração e controle dos orçamentos e balanços da União, dos Estados, dos Municípios e do Distrito Federal”, organizando, sistematizando e consolidando as normas sobre o orçamento público. Ainda vigente a maior parte de seus artigos, por não ter sido a lei substituída por outra mais recente, hoje tem status de lei complementar, atendendo ao disposto no art. 165 , $\$ 9^{\circ}$, e trazendo dispositivos que normatizaram o planejamento de prazo mais longo, além de estabelecer normas que consolidaram os orçamentos como instrumentos do planejamento governamental. O orçamento-programa, por exemplo, técnica que passa a exercer papel importante no planejamento, está previsto no art. $1^{\circ}$ da Lei n. 4.320, de 1964, ao estabelecer que a "Lei de Orçamento conterá a discriminação da receita e despesa de forma a evidenciar a política econômico-financeira e o programa de trabalho do Governo, obedecidos os princípios da unidade, universalidade e anualidade”. O art. 23 da Lei n. 4.320, de 1964, criou o Quadro de Recursos e de

92 BERCOVICI, Gilberto. Constituição econômica e desenvolvimento. Uma leitura a partir da Constituição de 1988, p. 72-73.

93 SOUZA, Nelson Mello e. O planejamento econômico no Brasil: consideraçôes críticas, p. 1704. 
Aplicação de Capital, a ser aprovado por decreto do Poder Executivo, de validade trienal, que foi o embrião dos atuais planos plurianuais, verdadeiro marco no âmbito do planejamento orçamentário da Administração Pública.

O governo militar que assumiu o poder em 1964 implantou o Programa de Ação Econômica do Governo (PAEG), voltado a promover o crescimento com estabilidade econômica. Nelson Mello e Souza vê-o não como um plano de governo, mas sim como "um conjunto de diretrizes de política econômica unificadas para atingir certos objetivos estabilizadores". ${ }^{4}$ Também não pode ser considerada uma experiência plenamente exitosa em termos de planejamento. Como registra Paulo Almeida, “o PAEG, mesmo não alcançando suas metas, logrou um nível razoável de estabilização econômica, efetuou uma importante reforma do Estado nas áreas gerencial e orçamentária, preparando as bases para o crescimento do país no período subsequente", ${ }^{55}$ resultando, por sua vez, em intensificação da desigualdade social.

A criação do IPEA (Instituto de Pesquisas Econômicas Aplicadas, surgido inicialmente como EPEA, Escritório de Política Econômica Aplicada), instituição dedicada a estudos sobre a economia brasileira, em muito contribuiu para as pesquisas que vieram a resultar em aperfeiçoamento do planejamento governamental.

A Constituição de 1967 surgiu em um momento político conturbado da História nacional, tendo em vista a deposição de João Goulart pelos militares e a instauração do novo regime político de exceção, com a nova Carta constitucional incorporando parte da filosofia dos detentores do poder à época.

Não por acaso, a Constituição de 1967 veiculou o vocábulo "planejar", insculpido no art. $8^{\circ}$, justamente o que trata da segurança nacional, vinculando planejamento a militarismo ("Art. $8^{\circ}$ Compete à União: (...) IV - organizar as forças armadas; planejar e garantir a segurança nacional”).

Em outras palavras, a cultura do planejamento passava a se inserir na Administração Pública nacional, muito embora a sua conotação tenha sido notadamente militar. Tanto é que, no âmbito constitucional, foi dada tal relevância ao planejamento da segurança nacional - a questão governamental mais sensível naquele momento histórico.

94 SOUZA, Nelson Mello e. O planejamento econômico no Brasil: considerações críticas, p. 1710.

95 ALMEIDA, Paulo Roberto de. A experiência brasileira em planejamento econômico: uma síntese histórica. In: GIACOMONI, James; PAGNUSSAT, José Luiz (Org.). Planejamento e orçamento governamental, p. 15. 
Os planos estabelecidos anteriormente continuaram tendo uma disciplina constitucional, acrescidos de outros em áreas diversas, mantendo-se o planejamento por planos. Os principais planos daquela Constituição foram: a) Plano Nacional de Viação (art. 8º, X); b) Planos Regionais de Desenvolvimento (art. 8º XIII); c) Planos Nacionais de Educação e Saúde (art. 8ª XIV); d) Planos de Valorização das Regiōes Menos Desenvolvidas do País (art. 65, $\$ 6^{\circ}$ ).

Importante avanço ocorreu com o Decreto-lei n. 200, de 1967, ainda vigente, que, ao organizar a Administração Pública federal, regulou aspectos relevantes do orçamento público e do planejamento na administração.

$\mathrm{O}$ art. $7^{\circ}$ expõe que a ação governamental obedecerá a um planejamento orientado ao desenvolvimento econômico-social, o qual deverá seguir os planos e os programas governamentais. Além disso, as alíneas do artigo em comento destacam caracteres tanto de planejamento econômico (como as alíneas a e b) quanto de planejamento orçamentário (tal como as alíneas $c$ e $d$ ).

Essa integração entre as duas modalidades de planejamento é observada também no Título III, que trata do planejamento, do orçamento-programa e da programação financeira. $\mathrm{O}$ art. 15 e parágrafos definem que a ação administrativa do Poder Executivo deve obedecer aos programas gerais, setoriais e regionais, de duração plurianual, com a responsabilidade de cada Ministério de orientar e dirigir a elaboração do programa setorial e regional correspondente à sua Pasta.

O planejamento orçamentário, realizado pelos Ministérios, continha uma característica fragmentária - o que foi mitigado a partir de 1988 com o advento do Plano Plurianual. O art. 22, I, exigia para as estruturas de cada Ministério Civil um órgão central de planejamento, coordenação e controle financeiro, tendo o art. 23, $\$ \$ 1^{\circ}$ e $3^{\circ}$, definido que a Secretaria Geral do Ministério do Planejamento e Coordenação Geral atuaria como órgão setorial do planejamento e orçamento para os fins do Título III supramencionado, além de exercer as atribuições de Órgão Central dos sistemas de planejamento e orçamento. A Lei n. $6.228 / 1975$ estenderia, posteriormente, por meio de seu art. $3^{\circ}$, essas atribuições ao extinto DASP.

$\mathrm{O}$ art. 16 integra o planejamento orçamentário nessa sistemática ao mencionar que, "em cada ano, será elaborado um orçamento-programa, que pormenorizará a etapa do programa plurianual a ser realizada no exercício seguinte e que servirá de roteiro à execução coordenada do programa anual”. E o art. 18 consolida essa integração ao definir que qualquer atividade deverá estar ajustada à programação governamental (planejamento econômico) e ao orçamento-programa (planejamento orçamentário). 
No entanto, o Decreto-Lei n. 200/1967, apesar de prever a integração entre os planejamentos, não previu uma figura que pudesse fazer essa "ponte plurianual" entre os programas e planos econômicos (PND, por exemplo) - intrinsecamente plurianuais - e o orçamento-programa, de característica anual - o que seria solucionado posteriormente com o Orçamento Plurianual de Investimentos (OPI).

$\mathrm{Na}$ Constituição de 1967, veem-se presentes as ideias de multianualidade ou plurianualidade, como se constata nas referências às despesas de capital: segundo o art. 63, parágrafo único, as despesas de capital, para serem previstas e realizadas, deverão obedecer à programação dos Orçamentos Plurianuais de Investimentos (OPI).

Diante disso, o art. $65, \S 4^{\circ}$, prescreve claramente que nenhum projeto, programa, obra ou despesa que se estenda além de um exercício financeiro poderá ter verba orçamentária no orçamento anual - nem sequer ser iniciado ou contratado - sem a inclusão prévia no OPI. O art. $65, \$ 6^{\circ}$, dispõe ainda que os orçamentos consignarão dotações plurianuais para a execução dos planos de valorização das regiōes menos desenvolvidas do País.

A Lei Complementar n. 3, de 1967, previu, em seu art. 5º, os Orçamentos Plurianuais de Investimento, abrangendo um período de três anos, contendo os programas setoriais, com especificação dos recursos a lhes serem anualmente destinados e os objetivos a serem atingidos (arts. $6^{\circ}$ e $7^{\circ}$ ), tendo sido posteriormente modificada pelos Atos Complementares ns. 43 e 76, de 1969. Do texto da norma, é possível perceber como o planejamento governamental orçamentário sempre esteve coligado ao planejamento governamental econômico no texto constitucional brasileiro, desde o advento da Lei n. 4.320, de 1964, que sistematizou, de forma inaugural, a dinâmica das finanças públicas no País.

Destaca-se na referida Lei Complementar o conceito de planos nacionais, utilizados nas Constituiçóes desde 1934, mas sem uma definição legal precisa a respeito. $\mathrm{O}$ art. $2^{\circ}$ prescreve o conceito de Plano Nacional: "conjunto de decisões harmônicas destinadas a alcançar, no período fixado, determinado estágio de desenvolvimento econômico e social". Um ponto importante a ser observado é a importância da periodicidade dada aos Planos, tornando-a como um elemento-chave para o planejamento governamental.

O parágrafo primeiro do referido artigo define a necessidade de o Plano Nacional ser apresentado mediante diretrizes gerais com as definições básicas adotadas, os elementos de informação que as justificarem e a determinação dos objetivos globais a serem perseguidos. 
$\mathrm{O}$ art. $3^{\circ}$ define que o Poder Executivo é responsável pela elaboração dos Planos Nacionais Quinquenais, a serem submetidos ao Congresso Nacional até o $1^{\circ} \mathrm{de}$ março anterior ao Plano Nacional em vigor, e com a obrigação de apreciação em até 120 dias $\left(\$ 1^{\circ}\right)$.

Vê-se uma integração entre o planejamento econômico governamental, representado pelos Plano Nacionais, com o planejamento orçamentário, nos Orçamentos Plurianuais de Investimento. O art. $5^{\circ}$ prescreve que o "Orçamento Plurianual de Investimentos é a expressão financeira dos programas setoriais regionais, consideradas, exclusivamente, as despesas de capital".

Uma questão interessante a ser destacada é a subordinação normativa do planejamento orçamentário da Administração Pública ao planejamento econômico governamental. O art. 12, I, da Lei Complementar n. 3/1967 determina que o Poder Legislativo deliberará a respeito da compatibilidade e da adequação dos objetivos selecionados no OPI com os objetivos do Plano Nacional.

Outro aspecto que também merece menção é o surgimento de uma subordinação hierárquica dos orçamentos dos demais entes subnacionais às diretrizes gerais para a elaboração e a execução do OPI. O art. 18, caput, é claro ao afirmar que os Estados, os Municípios e o Distrito Federal devem adaptar os seus respectivos orçamentos ao que dispóe a referida Lei Complementar.

O Ato Complementar n. 43, de 29 de janeiro de $1969,{ }^{96}$ criou os Planos Nacionais de Desenvolvimento, com duração equivalente ao mandato do Presidente da República, de iniciativa do Poder Executivo e aprovados pelo Congresso Nacional.

A Emenda Constitucional n. 1/1969 trouxe poucas alterações no que concerne à dinâmica do planejamento orçamentário governamental.

A partir de meados na década de 1970, a crise inflacionária fez com que o "planejamento" estivesse mais vinculado à estabilização econômica, o que não se caracteriza propriamente como um planejamento, não obstante o uso da expressão "planos" para fazer referência às medidas tomadas à época nesse sentido. Dessa forma, o País não conseguiria promover um planejamento sem uma estabilidade econômica que pudesse tornar previsíveis as estimativas realizadas. ${ }^{97}$ Por isso que, na realidade, não houve propriamente um menosprezo ao planejamento orçamentário, mas sim a sua total inviabilidade fática em razão do período de instabilidade econômica que o País passou a experimentar a partir desse período, de forma que

96 Posteriormente modificado pelo Ato Complementar n. 76, de 21 de outubro de 1969.

97 FRANCISCO, Jailton G.; FARIA, Maria Leonor; COSTA, Helder G. Planejamento e orçamento públicos: uma revisão da literatura. 
o planejamento orçamentário se tornava inócuo frente a um planejamento econômico ineficaz e tomado pelas incertezas próprias do período. Essa situação só melhorou a partir da consolidação do Plano Real (estabilidade monetária) e com os ajustes fiscais implementados (estabilidade fiscal), permitindo a concretização do planejamento orçamentário posteriormente.

Sob o comando dos governos militares, destacaram-se dois Planos Nacionais de Desenvolvimento. O I PND, no triênio 1972-1974 (Lei n. 5.727, de 4 de novembro de 1971), vigente no período de intenso crescimento, o chamado "milagre brasileiro", que se notabilizou por grandes projetos de integração nacional; e o II PND (Lei n. 6.151, de 4 de dezembro de 1974), no período 1975-1979, que se voltou à indústria de base e às questôes energéticas. O III PND (1980-1985), em face da crise vigente, mostrou-se irrelevante, sendo uma mera formalidade para cumprir a legislação vigente, dada a falta de unidade de comando na política econômica e as divergências quanto à forma de enfrentar os problemas à época. ${ }^{98}$

Fernando Rezende destaca a criação do Sistema Federal de Planejamento (SFP) em 1972, que formaliza o processo de planejamento na Administração Pública federal, tendo o Ministério do Planejamento como órgão central, que coordena os órgãos setoriais na elaboração dos planos e programas, e acompanha a execução, estabelecendo um fluxo permanente de informações e articulando as ações. ${ }^{99}$ Vê-se também a preocupação com a questão federativa, com o órgão central sendo incumbido de

"articular com os Estados, o Distrito Federal e os Municípios, a nível dos respectivos órgãos centrais de planejamento, mediante intercâmbio de informações e experiências, visando compatibilizar os Sistemas de Planejamento, bem como prestar assistência técnica para implementação de programas e projetos relacionados com planejamento, orçamento e modernização administrativa" (Decreto n. 71.353, de 9 de novembro de 1972, art. $6^{\circ}$ ).

A década de 1980 foi extremamente prejudicial para a evolução do planejamento no Brasil, em função da elevada inflação e da economia em declínio, com descontrole de contas públicas dos entes federados, impedindo a eficácia de qualquer ação voltada à coordenação e previsão das atividades governamentais.

Com a nova Constituição, em 1988, voltamos a observar avanços em relação ao planejamento, uma vez que o tema foi objeto de preocupação dos constituintes e o texto trouxe importantes dispositivos para regular esse aspecto da atuação estatal.

98 REZENDE, Fernando. Planejamento no Brasil: auge, declínio e caminhos para a reconstrução, p. 8.

99 REZENDE, Fernando. Planejamento no Brasil: auge, declínio e caminhos para a reconstrução, p. 6 . 
Destaque-se ainda nesse período a reforma da Administração Pública, materializada principalmente pelo Plano Diretor da Reforma do Aparelho de Estado, de 1995, voltada a introduzir conceitos de Administração Pública gerencial.

Durante os trabalhos da Assembleia Constituinte que levou à redação da Constituição promulgada em 1988, o grande avanço e novidade em relação ao planejamento orçamentário da Administração Pública deu-se com a criação da Lei do Plano Plurianual (PPA), destinada a integrar planos e orçamentos, cuja forma foi a que mais tempo levou para ser definida, e teve suas funçôes ampliadas durante as discussões - inicialmente, compreendia apenas os investimentos públicos e, depois, passou a incluir as despesas deles correntes até chegar à forma atual, em que abrange, além dos investimentos, os programas de duração continuada e a necessidade de regionalização. ${ }^{100}$ Não houve maior detalhamento de outras regras, acabando por assumir um caráter essencialmente orçamentário, de programação plurianual de despesas. ${ }^{101}$

O mesmo se observa com relação à Lei de Diretrizes Orçamentárias (LDO), instrumento inovador no âmbito da legislação orçamentária, em que se criou este "pré-orçamento", que tem como função principal definir as diretrizes para a elaboração da Lei Orçamentária Anual, precedendo-a em sua aprovação, o que permitiu

100 AFONSO, José Roberto Rodrigues. Orçamento e finanças públicas na elaboração da Constituição da República de 1988, p. 17-18.

101 O PPA, principal instrumento normativo hoje no Brasil do Pública, voltará a ser abordado neste trabalho de forma mais aprofundada, mas desde já fica o registro das críticas que Ronaldo Garcia pontua em relação a seu surgimento nos trabalhos da Assembleia Constituinte. O estudioso do tema observa com propriedade que "À época, já se dispunha de considerável evolução teórica e metodológica nas áreas de ciências e técnicas de governo e, principalmente, de experiências inovadoras e bem-sucedidas de planejamento estratégico governamental que poderiam ter informado as formulaçôes dos constituintes. Nos países desenvolvidos, praticavam-se modalidades diversas de planejamento estratégico público como requisito necessário à condução do governo em seu conjunto, e não apenas como algo relativo à organização da aplicação de recursos econômicos. Todavia, nada disto foi contemplado quando das definições constitucionais sobre o planejamento governamental. O PPA surgiu, portanto, em contexto no qual o planejamento governamental (de caráter normativo) estava em descrédito e sob forte crítica por parte dos ideólogos e defensores da onda neoliberal que se levantava poderosa. (...) Tais circunstâncias ajudam a compreender a natureza do PPA. A peça concebida pelos constituintes é, de fato, uma programação plurianual de despesas, chamada de plano por descuido ou por influência daqueles que lidavam com os PNDs. O PPA supõe plano de governo, cuja apresentação não está prevista. As despesas mencionadas pelo artigo 165 seriam aquelas que realizariam os objetivos do plano de governo, principalmente os que exigem investimentos. No entanto, na ausência de explicitação formal desta subordinação, o PPA passa a ser tomado como o substituto dos PNDs - inclusive em sua temporalidade inconveniente" (PPA: o que não é e o que pode ser, p. 58-59). 
melhorar a relação entre o Plano Plurianual e a Lei Orçamentária, ao criar vínculos jurídicos mais fortes entre eles, conferindo maior segurança jurídica ao sistema de planejamento orçamentário do Estado. Foi importante também por aumentar e melhorar a participação do Poder Legislativo no processo orçamentário, mostrando-se também uma boa alternativa à ideia inicial em discussão, de um orçamento com vigência bianual. ${ }^{102}$

A importância da Lei de Diretrizes Orçamentárias só fez crescer nos últimos anos, tendo suas funções incrementadas, especialmente após a publicação da Lei de Responsabilidade Fiscal, em 2000 (Lei Complementar n. 101), que lhe acrescentou importantes dispositivos legais. Destaca-se o anexo de metas e riscos fiscais, que deve estabelecer as metas para o ano a que se refere e os dois seguintes, o que reforça ainda mais o vínculo com o cumprimento das metas fixadas. Também as disposições sobre o equilíbrio de receitas e despesas, os critérios para limitação de empenho, normas para controle de custos e avaliação de resultados e as condições para a transferência de recursos a entidades públicas e privadas formam um conjunto de regras relevantes para a normatização das finanças públicas e o aperfeiçoamento do sistema de planejamento das ações governamentais.

Avanços em matéria de planejamento também se observam nas normas sobre a Lei Orçamentária, que deverá guardar compatibilidade com o Plano Plurianual $\left(\mathrm{CF}\right.$, art. $\left.165, \S 7^{\circ}\right)$, sendo vedado o início de programa ou projeto que nela não esteja previsto (CF, art. 167, I), nem a realização de investimentos cuja execução ultrapasse um exercício financeiro sem prévia inclusão no Plano Plurianual (CF, art. $\left.167, \$ 1^{\circ}\right)$.

A compatibilidade entre Plano Plurianual, Lei de Diretrizes Orçamentárias e Lei Orçamentária Anual é expressamente exigida pelo art. $5^{\circ}$ da Lei de Responsabilidade Fiscal, não deixando dúvidas quanto à inter-relação que faz das normas orçamentárias um sistema organizado em função do planejamento, criando um comprometimento do setor público com o seu efetivo cumprimento.

Os planos plurianuais, da forma como inicialmente começaram a ser implementados, permitem vislumbrar uma "redução" do planejamento ao orçamento, limitando em parte a ação planejadora do Estado de fixar diretrizes gerais para sua atuação; ${ }^{103}$ voltam-se mais claramente a exercer uma função própria do planeja-

102 AFONSO, José Roberto Rodrigues. Memória da Assembleia Constituinte de 1987/88: as finanças públicas, p. 15.

103 Conforme crítica de Gilberto Bercovici, em "O Planejamento do Estado não pode ser reduzido ao orçamento”. Ronaldo Garcia expõe o contexto histórico que justifica essa característica dos PPA: "O PPA surgiu, portanto, em contexto no qual o planejamento governamental (de cará- 
mento orçamentário da Administração Pública, destinado justamente a materializar as diretrizes gerais anteriormente estabelecidas. O que se observa é um direcionamento dos planos plurianuais para o âmbito da organização das finanças dos entes federados, e não do País como um todo, mesmo porque são leis de abrangência limitada ao ente federado que as editou.

O ordenamento jurídico nacional abrange outras normas, que compõem todo um sistema de planejamento, em que há avanços importantes.

Veja-se que a Constituição também cuidou do tema no aspecto setorial, criando instrumentos de planejamento voltados a áreas específicas da atuação governamental.

Cabe destaque, neste ponto, ao Plano Nacional de Educação, previsto no art. 214 da Constituição e tendo sido o primeiro criado pela Lei n. 10.172, de 9 de janeiro de 2001, válido para o período de 2001 a 2010, que estabeleceu como objetivos e prioridades a elevação do nível de escolaridade da população, a melhoria da qualidade de ensino, a redução das desigualdades no acesso à educação pública e a democratização da gestão do ensino público. Em 2014, foi publicada a Lei n. 13.005, instituindo o Plano Nacional de Educação para o período de 2014 a 2024.

Releva observar, no que tange aos aspectos jurídicos do planejamento no setor de educação, ${ }^{104}$ que se trata de norma que regula os gastos públicos em educação por prazo mais longo (dez anos) do que as leis de plano plurianual (quatro anos), o que é extremamente relevante para a organização da Administração Pública no âmbito nacional, de modo a uniformizar e coordenar a atuação governamental no setor.

É também importante ressaltar o fato de ser norma de caráter nacional, vinculando, portanto, todos os entes federados. No âmbito da educação, isso é de

ter normativo) estava em descrédito e sob forte crítica por parte dos ideólogos e defensores da onda neoliberal que se levantava poderosa. Ademais, muitos dos parlamentares integrantes da comissão da Assembleia Nacional Constituinte responsável pela elaboração das propostas para o que viria ser o Título VI (Da Tributação e do Orçamento) da CF/88 haviam sofrido com as dificuldades de planejar e executar orçamentos em ambiente de complexidade crescente e tinham se inclinado para orientação mais fiscalista. Tais circunstâncias ajudam a compreender a natureza do PPA. A peça concebida pelos constituintes é, de fato, uma programação plurianual das despesas, chamada de plano por descuido ou por influência daqueles que lidavam com os PND. O PPA supõe plano de governo, cuja apresentação não está prevista. As despesas mencionadas pelo artigo 165 seriam aquelas que realizariam os objetivos do plano de governo, principalmente os que exigem investimentos" (PPA: o que não é e o que pode ser, p. 435).

104 Tema que volta a ser abordado de forma mais específica e detalhada no item 7.1. 
fundamental importância, pois é área de atuação do Poder Público em que os entes federados cumprem função em regime de colaboração, evidenciando o federalismo cooperativo presente na organização do Estado brasileiro.

E é imprescindível, para que se possa planejar adequadamente a atuação do setor público nessas hipóteses, existirem normas que coordenem a atuação conjunta de todos os entes federados, estabelecendo as diretrizes que nortearão suas ações governamentais, de modo a conferir maior segurança jurídica em suas previsões de receitas e despesas, especialmente quanto às transferências intergovernamentais, fundamentais para a implementação das políticas públicas nesse setor.

Essa primeira lei que instituiu o Plano Nacional de Educação determinou que os Estados, o Distrito Federal e os Municípios elaborem seus planos decenais na área da educação (art. $2^{\circ}$ ), bem como seus planos plurianuais de modo a dar suporte às metas constantes do Plano Nacional de Educação e os respectivos planos decenais $\left(\right.$ art. $5^{\circ}$ ), de forma a criar um sistema normativo coeso, conferindo maior segurança jurídica e harmonia às finanças públicas na área educacional.

O segundo plano decenal de educação, vigente para o período de 2014 a 2024, estabeleceu dez diretrizes (art. $2^{\circ}$ ) e vinte metas, desdobradas em estratégias (art. $3^{\circ}$ e anexo) a serem cumpridas no período, determinando a Estados e Municípios que elaborem seus correspondentes planos de educação no prazo de um ano. ${ }^{105}$

Outra experiência brasileira importante que há de se destacar, neste breve registro sobre a evolução do planejamento governamental, foi a promovida pela Secretaria de Assuntos Estratégicos da Presidência da República no final da década de 1990, com a tentativa de elaboração de um planejamento de longo prazo. Ainda que sem características orçamentárias, que, como já mencionado, são menos viáveis em previsões dessa natureza, mostra a preocupação com o planejamento governamental em prazos superiores àqueles já estabelecidos pelo sistema de planejamento governamental consagrado e positivado em nosso ordenamento jurídico.

Elaborou-se à época o projeto Brasil 2020, que consistiu, como bem sintetizado por Paulo Roberto de Almeida, em um "exercício de reflexão, com o objetivo de traçar visões sobre o futuro do Brasil e, com isso, orientar a elaboração de alguns cenários exploratórios para guiar o itinerário brasileiro de desenvolvimento". ${ }^{106}$

105 O Estado de São Paulo só cumpriu a determinação em 2016, quando aprovou o Plano Estadual de Educação pela Lei n. 16.279, de 9 de julho de 2016.

106 ALMEIDA, Paulo Roberto de. A experiência brasileira em planejamento econômico: uma síntese histórica, p. 223. 
A tarefa consistiu em montar três cenários prospectivos para o Brasil no ano de 2020 e, com base neles, avaliar as possíveis alternativas para o desenvolvimento. Montaram-se os três cenários, chamados "cenários exploratórios", aos quais foram atribuídos os nomes indígenas de Abatiapé, Baboré e Caaetê, para, ao final, construir o cenário desejado, nominado Diadorim. Os cenários exploratórios "procuram analisar possíveis futuros alternativos, com base numa montagem técnica de combinações plausíveis de condicionantes e variáveis. Normalmente, não embutem desejos ou preferências de seus formuladores. Indicam, sobretudo, as diferentes alternativas de evolução futura da realidade dentro de limites de conhecimento antecipáveis", e o cenário desejado "é a expressão do futuro baseada na vontade de uma coletividade, refletindo seus anseios e expectativas e delineando o que se espera alcançar num horizonte dado", descrevendo "um futuro plausível", e não uma expressão de sonhos ou utopias, mas sim um "futuro que pode ser realizado como um desejo viável”. ${ }^{107} \mathrm{O}$ cenário Abatiapé via o Brasil como uma potência econômica sólida, porém com desequilíbrio social; o Baboré apresentava o Brasil como uma sociedade mais justa, mas com fraca participação no comércio exterior; e o Caaetê veiculava uma visão mais pessimista, com o Brasil enfrentando instabilidade política e perdendo espaço no mercado mundial. A partir desses cenários, construiu-se o cenário desejado, "Diadorim”, em que o Brasil é uma nação desenvolvida com equidade social, alta qualidade de vida elevado nível educacional, posição de destaque na economia mundial, economia sólida e dinâmica. ${ }^{108}$

Embora sem pretensões de se transformar em um documento de natureza e características orçamentais, representou uma experiência importante para o avanço das técnicas de planejamento governamental e reflexão sobre o futuro.

$\mathrm{Na}$ esfera internacional, o planejamento orçamentário da Administração Pública registra evolução importante, especialmente em face das açôes decorrentes da Comunidade Econômica Europeia. Em uma síntese dos estudos feitos por Nazaré Cabral nesse aspecto, pode-se constatar a influência planificadora da instituição, espacialmente no âmbito do microplanejamento, com verdadeiros "planos de gastos" (expenditure planning). Introduziu-se em 1988 um "sistema de perspectivas financeiras", que consiste em um "quadro financeiro plurianual adoptado conjuntamente pelas três instituiçôes com poderes orçamentais", e que

107 BRASIL. Presidência da República. Secretaria de Assuntos Estratégicos. Brasil 2020: Cenário Diadorim, esboço de um cenário desejável para o Brasil, p. 1.

108 ALMEIDA, Paulo Roberto de. A experiência brasileira em planejamento econômico: uma síntese histórica, p. 223-225. 
resultaram no Pacote Delors I, com as perspectivas financeiras para o período de 1988 a 1992, o Pacote Delors II, para o período de 1993 a 1999, e o Acordo Interinstitucional de 1999 , compreendendo as perspectivas financeiras para o período de 2000 a $2006 .{ }^{109}$

$\mathrm{Na}$ história mais recente do planejamento orçamentário governamental brasileiro, os avanços mais relevantes ocorrem a partir de 1990, quando surgiram os primeiros planos plurianuais segundo os termos da nova Constituição, sobre os quais trataremos em capítulo à parte, com análise mais acurada de suas características e evolução ao longo de cada uma das novas edições. Far-se-á, a seguir, tão somente uma visão panorâmica, apenas para a finalidade de completar a evolução histórica do planejamento governamental brasileiro.

No que tange aos planos plurianuais no âmbito federal, a lei que instituiu o primeiro elaborado nos termos da nova Constituição surgiu no governo do Presidente Fernando Collor, válido para o período de 1991 a 1995, com uma revisão efetuada em 1992, mas se mostrou incipiente, e pouca relevância acabou tendo para a finalidade a que se prestava.

Não obstante importante historicamente por ser o primeiro plano plurianual elaborado nos termos previstos pela nova Constituição, apenas em 1995, no governo do Presidente Fernando Henrique Cardoso, estabilizada a moeda nacional pelo advento do "Plano" Real, surge o primeiro plano plurianual que efetivamente permite reconhecer a retomada do planejamento governamental no Brasil.

O PPA 1996-1999 introduziu os conceitos dos eixos nacionais de integração e desenvolvimento, com o objetivo de estabelecer uma "estratégia de desenvolvimento para o Brasil que permitisse a redução dos desequilíbrios regionais e sociais", levando em consideração, para fins de planejamento, os aspectos regionais e a necessidade de integração e fomento ao desenvolvimento das regiōes menos favorecidas. ${ }^{110}$ Complementado pelo Programa "Brasil em Ação", de agosto de 1996, que selecionou ações do PPA em setores estratégicos nas áreas de infraestrutura econômica e desenvolvimento social para priorizá-las e implantá-las, com a utilização de técnicas modernas de Administração Pública para gerenciamento de projetos, consolidou-se o processo de modernização da Administração Pública com ênfase no planejamento.

109 CABRAL, Nazaré da Costa. Programação e decisão orçamental. Da racionalidade das decisões orçamentais à racionalidade econômica, p. 226-227.

110 BRASIL. Ministério do Planejamento, Orçamento e Gestão. Secretaria de Planejamento e Investimentos Estratégicos. O desafio do planejamento governamental, p. 14. 
Registre-se também no período o início do aperfeiçoamento dos recursos humanos na área pública, com a seleção e formação de analistas de planejamento e orçamento e o treinamento de pessoal, com cursos voltados a essa temática. ${ }^{111}$

Em maio de 2000, é publicada a Lei de Responsabilidade Fiscal (Lei Complementar n. 101, de 2000), que, apesar de ter sido vetado o único artigo destinado a tratar especificamente do Plano Plurianual (art. $3^{\circ}$ ), trouxe alguns aperfeiçoamentos, principalmente pela introdução de dispositivos legais que criaram vínculos entre os planos plurianuais e as demais leis orçamentárias. $\mathrm{O}$ mais relevante deles é o Anexo de Metas Fiscais, obrigação legal que passa a integrar a Lei de Diretrizes Orçamentárias, documento que deve conter "as metas anuais, em valores correntes e constantes, relativas a receitas, despesas, resultados nominal e primário e montante da dívida pública, para o exercício a que se referirem e para os dois seguintes" (Lei Complementar n. 101, art. 4o,$\$ 1^{\circ}$ ).

O PPA 2000-2003, primeiro após a Lei de Responsabilidade Fiscal, representou uma grande evolução no aperfeiçoamento e na modernização da gestão pública, organizando as açóes em programas - com indicadores de resultados, previsão orçamentária e designação de gerentes - criados a partir do planejamento, tornando o gestor focado nos resultados, e não mais nos procedimentos, representando um dos mais relevantes marcos em termos de avanço no planejamento.

A reorganização da Administração Pública federal, com a fusão do Ministério do Planejamento e Orçamento com o Ministério da Administração e Reforma do Estado, criando o Ministério do Planejamento, Orçamento e Gestão, colaborou para dar o necessário apoio administrativo à nova forma de conduzir a Administração Pública, agora com foco claro no planejamento e na modernização da gestão pública.

O PPA 2004-2007, o "Brasil de Todos", destacou-se por ter sido elaborado a partir de ampla participação democrática, com a realização de fóruns de participação social em todas as unidades da federação, para ouvir a sociedade e definir os rumos do planejamento.

O "Desenvolvimento com inclusão social e educação de qualidade" denominou e deu a marca do PPA 2008-2011, voltando suas preocupaçôes para o desenvolvimento, com aceleração do crescimento econômico, redução das desigualdades sociais e regionais e promoção da inclusão social, priorizando a educação.

111 BRASIL. Ministério do Planejamento, Orçamento e Gestão. Secretaria de Planejamento e Investimentos Estratégicos. O desafio do planejamento governamental, p. 18. 
O PPA 2012-2015, "Mais Brasil: mais desenvolvimento, mais igualdade, mais participação", pretendeu intensificar a atuação do Estado como indutor e promotor das mudanças necessárias para a construção de um país mais moderno e igualitário, por meio de políticas públicas construídas de forma participativa e respeitando o pacto federativo.

O PPA 2016-2019, intitulado "Desenvolvimento, produtividade e inclusão social”, veio com a intenção de construir e consolidar "um modelo de desenvolvimento econômico, social e ambiental orientado pela inclusão social e pela redução das desigualdades", por meio do "aperfeiçoamento das políticas públicas na busca pela melhor distribuição das oportunidades e do acesso a bens e serviços públicos de qualidade por toda a população brasileira". ${ }^{112}$

O PPA 2020-2023, "Planejar, priorizar, alcançar", propôs trazer como inovações a simplificação metodológica, o realismo fiscal e o alinhamento com os planejamentos estratégicos dos ministérios e integração com a avaliação de políticas públicas.

Nota-se nos últimos planos plurianuais federais uma preocupação com políticas públicas de âmbito nacional, voltadas ao desenvolvimento econômico e social, ampliando-se gradativamente suas funções e abrangência, com destaque para as "agendas transversais", que receberam tratamento especial no PPA 2012-2015 para atender às políticas públicas transversais e multissetoriais.

A partir de 2012, o sistema de planejamento orçamentário tem experimentado um retrocesso, marcado principalmente pela desconsideração da Lei de Diretrizes Orçamentárias, cujas metas fiscais têm sido reiteradamente descumpridas e alteradas, e seu processo legislativo desrespeitado, sendo aprovada completamente fora do prazo legal, por vezes conjuntamente com a Lei Orçamentária, como ocorreu várias vezes nos últimos anos, ${ }^{113}$ como se viu no ano de 2016.

112 BRASIL. Ministério do Planejamento, Orçamento e Gestão. Secretaria de Planejamento e Investimentos Estratégicos. Plano plurianual 2016-2019. Desenvolvimento, produtividade e inclusão social. Projeto de lei. Mensagem presidencial, p. 9.

113 CONTI, José Mauricio. 2015: o ano de triste memória para o Direito Financeiro que não quer terminar, Levando o direito financeiro a sério, p. 483-488. 